\title{
Devonian brachiopods of the Cantabrian Mountains (Northern Spain). 12) Ferronirhynchia new genus, an Upper Emsian rhynchonellid (Trigonirhynchiidae)
}

\author{
Braquiópodos devónicos de la Cordillera Cantábrica (Norte de España). 12) Ferronirhynchia nuevo \\ género de rinconélido (Trigonirhynchiidae) del Emsiense Superior
}

\author{
Jenaro L. GARCÍA-ALCALDE (1)
}

\begin{abstract}
The taxonomic status of the subfamily Trigonirhynchiinae is discussed based on the morphological features, together with the geographic and the stratigraphic distribution of the type genus Trigonirhynchia Cooper. The new genus, Ferronirhynchia n. gen., including the type species F. pulgari n. sp., is proposed. The new taxon, close to Trigonirhynchia, occurs in upper Emsian beds of the Moniello Formation, in Asturias, serotinus/patulus conodont zones, Faunal Intervals 14-16a. The ontogeny and palaeoecology of $F$. pulgari are analyzed. Growth of the new species is bicyclic. Juvenile forms are low and biconvex displaying sharp commissures. Adult forms are high, dorsi-biconvex, geniculate, with abrupt anterior and lateral margins. Ferronirhynchia pulgari is an opportunistic species, often found in paraautochtonous rhynchonellid assemblages that occur in quiet and muddy deposits formed below the wave-base level near or in reefal environments in the Cantabrian platfom. Shells of the new species supported a variety of small epizoans, commensalists or mutualists, mostly reticulate bryozoans, serpulid and other tubeworms, and auloporids. This life habit favoured the epizoans to escape from burial in muddy bottoms.

Resumen: Se analiza la sistemática de la Subfamilia Trigonirhynchiinae, discutiendo los rasgos morfológicos y la extensión geográfica y estratigráfica del género tipo, Trigonirhynchia. Se propone el nuevo género Ferronirhynchia, próximo a Trigonirhynchia, compuesto por su especie-tipo F. pulgari n. sp., de edad Emsiense superior, zonas de conodontos serotinus/patulus, Intervalos Faunisticos 14-16a de la Formación Moniello en Asturias. Se analizan la ontogenia y las condiciones paleoecológicas generales de la especie. Se trata de una forma con crecimiento bicíclico: conchas juveniles biconvexas, bajas, de comisuras cortantes y adultas dorsibiconvexas, bastante altas, geniculadas, con paredes laterales y frontal abruptas. El nuevo taxon es una especie oportunista, frecuente en asociaciones paraautóctonas de rinconélidos de medios fangolíticos que existieron bajo el nivel de las olas, cerca de ambientes arrecifales en la plataforma cantábrica. El permanente riesgo de asfixia por enterramiento en fondos blandos fangosos provocó que las conchas de Ferronirhynchia pulgari actuasen como soporte de una variada fauna de pequeños epizoos comensalistas (o mutualistas): briozoos reticulados, serpúlidos y otros tubículas y aulopóridos, principalmente.
\end{abstract}

Received: 30 October 2020

Accepted: 3 March 2021

Published online: 22 June 2021

Corresponding author:

Jenaro L. García-Alcalde

jalcalde@uniovi.es

\section{Keywords:}

Ferronirhynchia n. gen.

Brachiopods

Trigonirhynchiinae

Biostratigraphy

Palaeoecology

\section{Palabras-clave:}

Ferronirhynchia n. gen.

Braquiópodos

Trigonirhynchiinae

Bioestratigrafía

Paleoecología

\section{INTRODUCTION}

The taxonomy of certains brachiopod groups are problematic due to the presence of marked homeomorphy between taxa with distant affinities. García-Alcalde (2009) and García-Alcalde and Herrera (2015) pointed it out this situation, specifically for the family Trigonirhynchiidae Schmidt, 1965 of the superfamily Rhynchotrematoidea but, in particular, for the subfamily Trigonirhynchiinae Schmidt, 1965. This subfamily included several genera with external shape close to Trigonirhynchia Cooper, 1942 but without a true median dorsal septum, which is replaced by a pseudoseptum (sensu Rozman, 1969 fide Havlíček \& Štorch, 1990; García-Alcalde, 1998). The later is a simple bulging of the valve bottom that grows in height by apposition of successive laminae of secondary shell, joining to the septalial plates forming a pseudoseptalium. García-Alcalde (2009) grouped all these forms into a new family, Iberirhynchiidae, belonging to the superfamily Ancistrorhynchoidea, based on the pseudo-septalial dorsal structures.

Nonetheless the precise meaning of the family Trigonirhynchiidae remains seriously affected by the inadequate interpretation of the type genus, Trigonirhynchia Cooper, 1942. This genus, according to Savage (2002), includes forms from the middle Silurian to the lower Eifelian from Europe, North

(C) The Author(s) 2021. This is an open-access article distributed under the terms of the Creative Commons Attribution 4.0 International License (for details please see http://creativecommons.org/licenses/by/4.0/), which permits use, copy, adaptation, distribution, and reproduction in any medium or format, as long as you give appropriate credit to the original author(s) and the source. 
America, Siberia, China, and Mongolia. However, a quick review of Silurian species (such as $T$. sulcata auct., T. stricklandi auct., and T. tennesseensis auct.) suggests that they belong most likely to the genus Boucotella Bowen, 1966, a taxon of the Uncinuloidea. Trigonirhynchia acutirostella Amsden, 1958, from the Lochkovian of North America, without dental plates as well as septalial connectivum, and with very massive internal structures, does not fit the features of Trigonirhynchia. The Siberian and Mongolian forms, in particular Trigonirhynchia ventricosa (Alekseeva, 1967), T. ventricosa tarejaensis Tcherkesova, 1969, and T. tsaganensis Erlanger in Alekseeva et al., 1981, would rather belong to Ancillotoechia, to which $T$. ventricosa was originally assigned, or to another close form. This interpretation is based on the presence of a pseudoseptum visible in drawings of serial sections (see Alekseeva et al., 1981), low number of ribs with an average median formula $4 / 3$, rather elongated outline, and occurrence of a deep mid dorsal sulcus in the umbonal region. The occurrence of a pseudoseptum is also probable in Trigonirhynchia jurata Baranov, 1991, a form close to Iberirhynchia Drot \& Westbroek, 1966, as well as in $T$. postventricosa, according to the serial sections provided by Tcherkesova (1969, figs. 4-5). Tcherkesova (op. cit.) did not provide serial sections of her new species $T$. latiuscula. But the small size of that species, reduced number of costae with median formula $4 / 3$, and the dorsal fold ribbing which seems to be born by bifurcating pairs of ribs near the apex, supports that it does not belong to Trigonirhynchia. North American forms, assigned with uncertainty to some of the Siberian species, such as $T$. ventricosa variabilis (Brice, 1982) (originally included, with doubts, in Ancillotoechia), from Arctic Canada, have a very wide and short median dorsal septum. This, together with the occurrence of a strong external dorsal umbonal groove makes this form a taxon likely belonging to the family Iberirhynchiidae. The small size of $T$. ventricosa variabilis, the flat or convex septalial connectivum, the low number of ribs with median costal formula $4 / 3$, with the two ribs that start the dorsal fold unfolding into two others, the somewhat concave dental plates, and the lack of marginal spines, are morphological characters to feasibly separate it from Trigonirhynchia. Trigonirhynchia? aff. T. ventricosa ventricosa, described and figured by Soja (1988), from SE Alaska, lacks a septalial connectivum and, according to the morphology of the dorsal fold and the occurrence of a well-developed median groove in the dorsal umbonal region, it could also be an Ancistrorhynchoidea close to $T$. ventricosa variabilis. The same can be argued for $T$. aff. $T$. occidens Perry, Klapper \& Lenz, 1974, from Nevada and Arctic

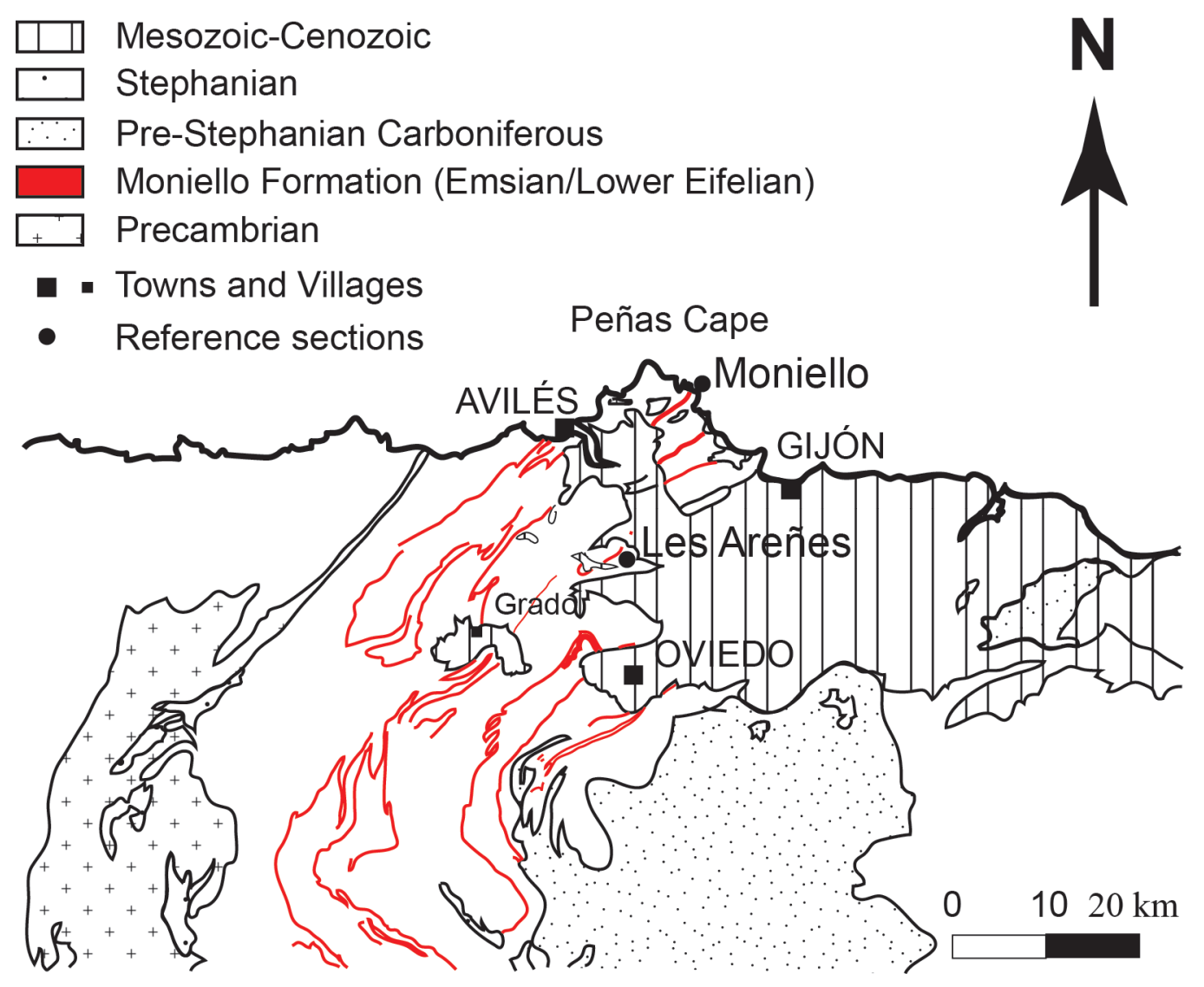

Figure 1. Position of the main sections sampled for Ferronirhynchia pulgari n. gen. $\mathrm{n}$. sp. and exposures of the Moniello Formation (red line) (Lower-Middle Devonian) in Asturias (N Spain). Modified from García-Alcalde (2015), with permission from the bulletin Trabajos de Geología, Universidad de Oviedo. 
Canada as described by Jones and Smith (1985). The specimens cited by Perry (1984) as T. cf. T. occidens, from the Lochkovian of Canada, are only a handful of juvenile specimens of doubtful affinities probably belonging to the superfamily Ancistrorhynchoidea. Drot (1971) described Trigonirhynchia fallaciosa from the Siegenian of Morocco, based on a single internal mould, but García-Alcalde (1998) questioned this taxonomic attribution, assigning the specimen to the genus Cerveratoechia García-Alcalde, 1998. Mergl and Massa (2004) cited Trigonirhynchia sp. in Algeria based on three incomplete ventral valves but the morphology of the only figured valve does not fit in the genus. On the other hand, several authors included in Trigonirhynchia species of Oligoptycherhynchus Sartenaer, 1970 such as O. daleidensis (Roemer, 1844); i.e., Jahnke (1971) for German material, Ahmadzadeh-Heravi (1975) for Iranian material, and Iordan (1998) for material from Romania, and O. pareti (Verneuil in Prado \& Verneuil, $1850)$; i.e., Westbroek $(1967,1969)$ for material from Spain. Lack of enough and adequate data precludes taxonomic discussion of part of the Chinese material included in the genus Trigonirhynchia.

In summary, there are good reasons to remove from Trigonirhynchia all species from Siberia, Mongolia, and North Africa, as well as most of those from North America. A possible exception would be Trigonirhynchia occidens (Walcott, 1884) from the Emsian of Nevada (USA), described in modern terms by Johnson (1970). References to pre-Devonian and Lochkovian forms are also rejected. Trigonirhynchia would be restricted to the Pragian-lower Eifelian? interval. It would be represented in the Pragian of France by its type species, T. fallaciosa (Bayle, 1878), in the upper part of the lower Pragian of Spain by T. palentina García-Alcalde \& Herrera, 2015 and T. celtiberica García-Alcalde \& Herrera, 2015, perhaps in the Emsian of Nevada by $T$. occidens (Walcott, 1884), and in the lower Eifelian? of Iran by T. iranica Brice (in Brice et al., 2006).

\section{MATERIALS AND METHODS}

The studied fossil collection is housed at the Museum of the Geology Department, University of Oviedo (Spain). It includes more than five hundred specimens coming from the type-locality and other Asturian localities, lower and middle members of the Moniello Formation, serotinus to patulus conodont zones, late Emsian. DPO numbers stands for Museum of the Department of Geology (Paleontology), Oviedo University.

The descriptive terminology is based on Kaesler (2002) and Selden (2007). The studied fossil specimens were highlighted with QP Panreac magnesium metal powder, photographed by the author with a digital camera

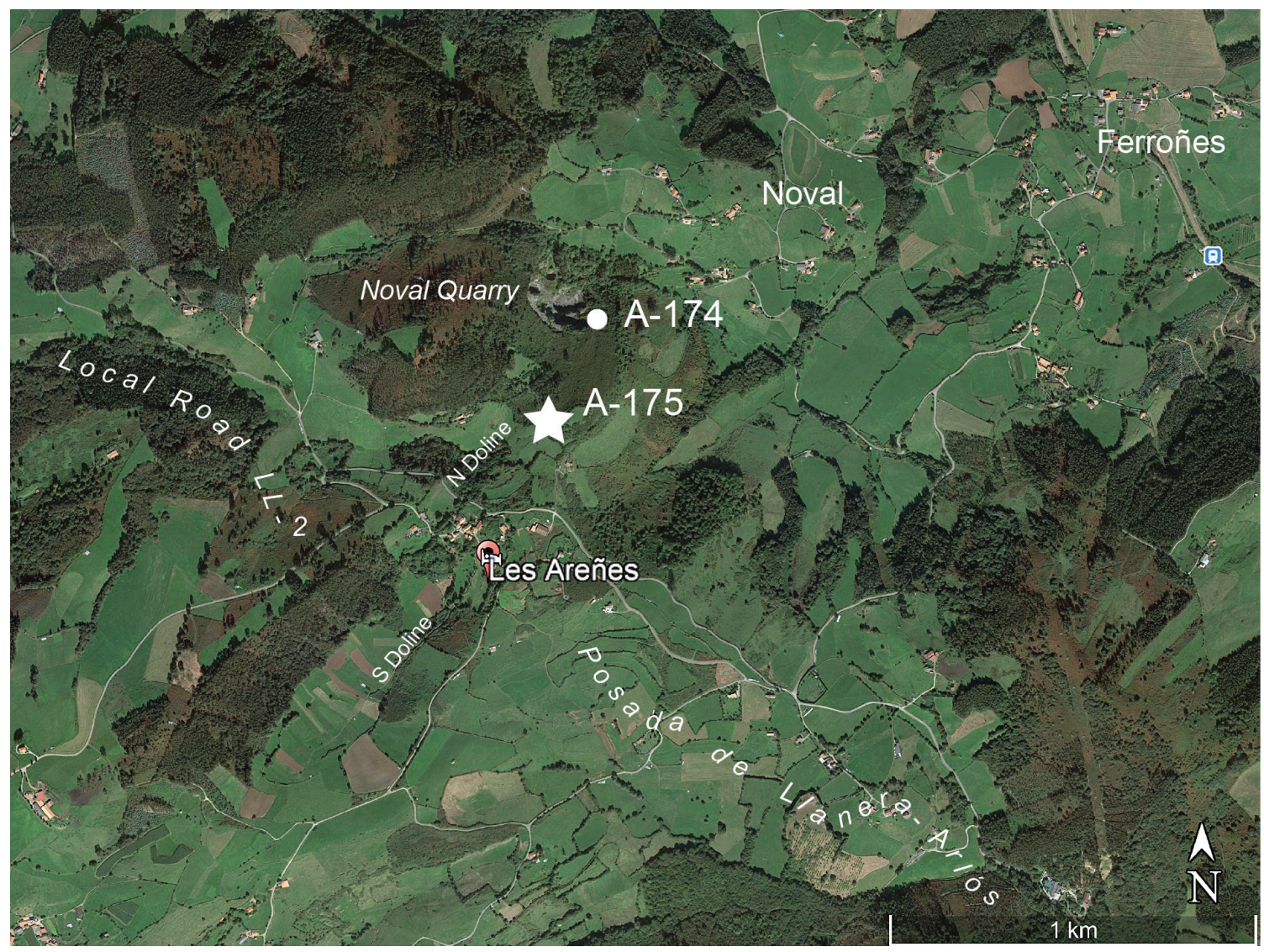

Figure 2. Location of the main fossiliferous sites of Ferronirhynchia pulgari n. gen. n. sp. in the type area, north Les Areñes village. White star: stratotype, level A-175. White circle: level A-174, lateral prolongation of the stratotype in the Noval limestone quarry. Aerial view in Google Earth Pro. 
LES AREÑES

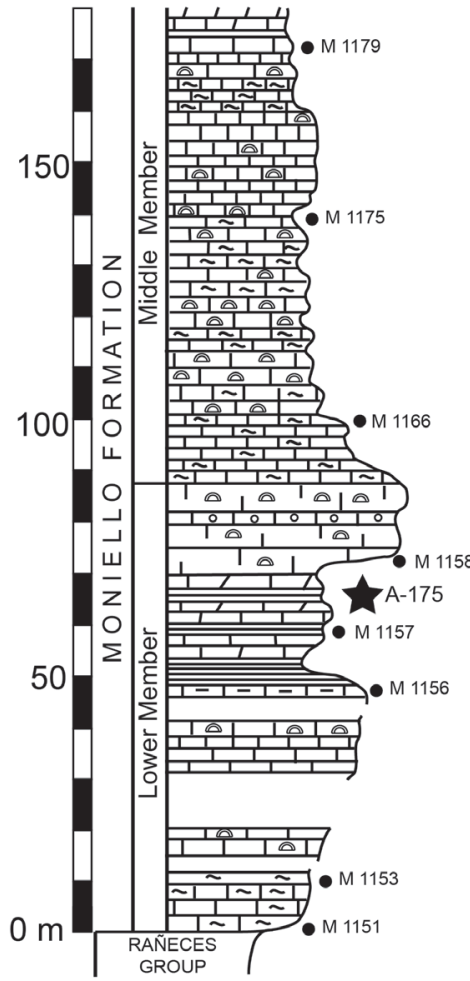

Discontinuous outcrops of reddish and gray limestones, dolomitized at the top with big gastropods

Reddish and gray limestones with fragmented stromatoporoids

Reddish and gray birdseye limestones with auloporoids and gastropods

Alternance of coral and birdseye limestones

Reddish and gray birdseye limestones with gastropods

Massive limestones with some levels of crinoidal limestones. Corals abundant. Big massive stromatoporoids at the top

Partially dolomitized reddish and gray limestones with interbedded marls and shales

Marls and shales

Discontinuous outcrops of gray limestones with fragmented stromatoporoids

Red coral limestones

Reddish and gray birdseye limestones

Figure 3. Composed stratigraphic column based on discontinuous Moniello Formation outcrops located on the edges of Les Areñes North Doline and ca. 300 m NNE of the Noval quarry. According to Méndez-Bedia (1976) and new data herein. Samples M 1151, 1153 and so on, after MéndezBedia (op. cit.).

Panasonic Lumix DC-TZ90 4K with an optical zoom $30 \mathrm{x}$, and with an intelligent zoom 60x, and prepared for illustration with Adobe Photoshop CC (64 Bit) and Adobe Illustrator (64 Bit) software. The serial sections drawings were accomplished with a camera lucida Wild, $V=1.2 x$, attached to a binocular microscope Wild Heerbrugg M5-96947.

\section{SYSTEMATIC PALEONTOLOGY}

Phylum BACHIOPODA Duméril, 1806

Order RHYNCHONELLIDA Kuhn, 1949

Superfamily RHYNCHOTREMATOIDEA Schuchert, 1913

Family TRIGONIHYNCHIIDAE Schmidt, 1965

Subfamily TRIGONIHYNCHIINAE Schmidt, 1965

Ferronirhynchia n. gen.

Type-species. Ferronirhynchia pulgari n. sp. Late Emsian; Asturias (North Spain).

Derivatio nominis. From the Ferroñes parish, where the type locality of Ferronirhynchia pulgari n. sp. occurs, and from the Greek suffix rhynchos = beak, alluding to the pinched aspect of the ventral umbo.
Diagnosis. Shell subtriangular to subpentagonal in outline, medium-sized, with bicyclic growth; young forms very low, ventribiconvex to biconvex (concha plana stage, Westbroek, 1967) with sharp commissures; adult forms moderately high and dorsibiconvex (concha alta stage, Westbroek, 1967) with precipitous anterior and lateral margins. Faint ventral sinus and dorsal fold with the latter flattened or medially sulcated to the anterior margin or nearly so; moderately high, trapezoidal, ventral tongue, maximum shell height behind to the anterior margin of shell. Neanic region of shell divided by a strong intra-neanic growth line coinciding with the starting point of the ventral sulcus and the dorsal fold. Costae strong, simple, angular, starting from the beaks; marginal spines developed in adults; strongly crenulated, anterior and antero-lateral commissures. Faintly excavated muscle scars. Well-developed squamae and glottae. Parallel, relatively long, dental plates. Great, cupulifom septalium covered distally by a tectiform connectivum; crura raduliform.

Discussion. Trigonirhynchia Cooper, 1942 is a closely related genus but it differs from Ferronirhynchia by its markedly dorsibiconvex profile, cuboid aspect, shell as thick as long, equidimensional to slightly elongated, high and arched tongue, very incurved ventral beak that suggests that species of the genus lacked a functional pedicle at least in adult stages, obtuse apical angle, dorsally convergent or divergent dental plates, and strongly excavated muscle scars.

Stenorhynchia Brice, 1981 is also a close taxon but the shells are usually very high, strongly dorsibiconvex, with maximum height at the anterior margin of shell or very near of it, wider ventral sulcus and dorsal fold, lacking parietal ribs (according to Brice, 1981, but see Sartenaer, 2009), very narrow lateral flanks, very high and arched ventral tongue, suberect to incurved beak, obtuse apical angle, very weak, limited to the umbonal region mid-dorsal depression, and lack of marginal spines (after Brice, 1981; but see Savage, 2002). The occurrence of a complete connectivum in Stenorhynchia is highly debatable (compare Havlíček, 1961; Brice, 1981; Havlíček \& Štorch,1990; see García-Alcalde, in Truyols-Massoni \& García-Alcalde, 1994). It seems that the type species of Stenorhynchia, Terebratula nympha (Barrande, 1847), from Bohemia, is not the same species as the La Lezais form (Armorican Massif) on wich Brice (1981) essentially described her new genus. The Armorican material would belong rather to Stenorhynchia briceae García-Alcalde (in TruyolsMassoni \& García-Alcalde, 1994) as suggested by García-Alcalde (op. cit.) and perhaps accepted by Brice (2000) according to Sartenaer (2009, p. 34). Assuming Stenorhynchia is a valid genus, S. briceae García-Alcalde, as well as the Armorican material included in S. nympha by Brice (1981) would belong to another genus, i.e., Xahetomus Sartenaer, 2009, close to Oligoptycherhynchus Sartenaer, 1970. The present author approximated earlier the type species 
of Ferronirhynchia to Oligoptycherhynchus (see below, synonymy list). The latter taxon, however (according to the emended diagnosis by Sartenaer, 2007), as well as Xahetomus, differ from Ferronirhynchia by the transversely sub-cordiform to subcircular or subovate outline, strongly dorsibiconvex profile, with maximum height at the frontal margin or very near of it, ventral sulcus and dorsal fold highly developed and beginning in the umbonal region at a short distance from the beaks, more incurved ventral beak, obtuse apical angle, very high and subrectangular ventral tongue, and parietal costae common.
Ferronirhynchia pulgari $\mathrm{n}$. $\mathrm{sp}$.

Figures 4-11, Table 1

v. 1976 Oligoptycherhynchus hexatoma (Schnur); MéndezBedia, p. 35.

v. 1979 Oligoptycherhynchus hexatoma; García-Alcalde (in García-Alcalde et al., eds.), fig. 6.

v.? 1979 Oligoptycherhynchus cf. hexatoma; García-Alcalde (in García-Alcalde et al., eds.), p. 15.

v. 1979 Oligoptycherhynchus hexatoma; García-Alcalde (in Arbizu et al.), fig. 4.

v. 1996 Oligoptycherhynchus? hexatoma; García-Alcalde, fig. 2.

Table 1. Ferronirhynchia pulgari n. gen. n. sp. Measurements of the holotype and paratypes. L, w, t, length, width, thickness (in $\mathrm{mm}$ ); $\boldsymbol{\alpha}$, apical angle (in sexagesimal degrees); wsin/w, sinus width to shell width ratio (percent of width); StSin, Start of the sinus ventral and dorsal fold related to the length (percent of length); Setw, Setting of the width related to the $L$ (percent of length); P, Paratype; HOL, Holotype.

\begin{tabular}{|c|c|c|c|c|c|c|c|c|c|}
\hline DPO & $\mathbf{L}$ & w & $t$ & $w / L$ & $t / L$ & $\alpha$ & $w \sin / w$ & StSin & Setw \\
\hline P49090 & 16.5 & 19.9 & 11.5 & 1.21 & 0.7 & 92 & 60 & 56 & 63 \\
\hline P49091 & 16.3 & 19 & 11 & 1.17 & 0.67 & 96 & 63 & 44 & 61 \\
\hline P49092 & 16.7 & 18.8 & 13.6 & 1.13 & 0.81 & & & & \\
\hline P49093 & 15.6 & 17.9 & 9.8 & 1.15 & 0.63 & 82 & 78 & 44 & 67 \\
\hline P49094 & 14.7 & 17.2 & 10.6 & 1.17 & 0.72 & 83 & 57 & 43 & 71 \\
\hline P49095 & 15.8 & 18.3 & 7.7 & 1.16 & 0.49 & 76 & 57 & 42 & 66 \\
\hline HOL49096 & 15.1 & 17 & 8.7 & 1.13 & 0.58 & 74 & 68 & 55 & 69 \\
\hline P49097 & 14.5 & 17.2 & 8.2 & 1.19 & 0.56 & 84 & 56 & 38 & 62 \\
\hline P49098 & 14.7 & 16.1 & 8.3 & 1.09 & 0.56 & 70 & 50 & 54 & 71 \\
\hline P49099 & 13.5 & 15.9 & 10 & 1.18 & 0.74 & & & & \\
\hline P49100 & 14.2 & 15.9 & 8.4 & 1.12 & 0.59 & 70 & 48 & & 56 \\
\hline P49101 & 13.8 & 14.8 & 10.5 & 1.07 & 0.76 & 76 & 57 & 52 & 73 \\
\hline P49102 & 12.5 & 14.2 & 9.6 & 1.14 & 0.77 & 86 & 52 & 67 & 67 \\
\hline P49103 & 13.2 & 14.9 & 10.1 & 1.13 & 0.68 & & & & \\
\hline P49104 & 12.8 & 14.7 & 6.8 & 1.15 & 0.53 & 78 & 61 & 52 & 70 \\
\hline P49105 & 12.8 & 14.1 & 6.5 & 1.1 & 0.51 & & & & \\
\hline P49106 & 13.6 & 14 & 8.1 & 1.03 & 0.59 & & & & \\
\hline P49107 & 12.8 & 14.6 & 6.2 & 1.14 & 0.48 & 85 & 63 & 48 & 66 \\
\hline P49108 & 12.4 & 13.3 & 8.6 & 1.07 & 0.69 & & & & \\
\hline P49109 & 12.6 & 13.5 & 7.3 & 1.07 & 0.58 & & & & \\
\hline P49110 & 12.9 & 13.7 & 7.8 & 1.06 & 0.60 & & & & \\
\hline P49111 & 12 & 12.5 & 6.5 & 1.04 & 0.54 & 56 & 58 & 59 & 71 \\
\hline P49112 & 12.1 & 12.4 & 5.4 & 1.02 & 0.45 & 80 & 56 & 58 & 75 \\
\hline P49113 & 11.5 & 12.4 & 5.2 & 1.08 & 0.45 & 87 & 61 & 53 & 70 \\
\hline P49114 & 10.9 & 11.9 & 5.4 & 1.09 & 0.49 & & & & \\
\hline P49115 & 11.7 & 12.3 & 6.1 & 1.05 & 0.52 & & & & \\
\hline P49116 & 11.5 & 12 & 5.1 & 1.04 & 0.44 & 75 & 59 & 43 & 68 \\
\hline P49117 & 11.4 & 11.3 & 4.6 & 0.99 & 0.40 & 70 & 61 & 59 & 69 \\
\hline P49118 & 9.8 & 10.5 & 4.6 & 1.07 & 0.47 & & & & \\
\hline P49119 & 9.5 & 10.2 & 4 & 1.07 & 0.42 & 68 & 52 & 91 & 64 \\
\hline P49120 & 9.8 & 8.8 & 4.3 & 0.9 & 0.44 & 75 & 57 & 38 & 68 \\
\hline P49121 & 9.6 & 9.4 & 3.9 & 0.98 & 0.41 & 80 & 73 & 39 & 72 \\
\hline P49122 & 9.4 & 8.9 & 3.8 & 0.95 & 0.4 & 63 & 54 & 50 & 70 \\
\hline P49123 & 9.1 & 8.8 & 3.7 & 0.97 & 0.41 & 74 & 67 & 73 & 65 \\
\hline P49124 & 8.2 & 8.2 & 3.7 & 1 & 0,45 & 76 & 56 & 58 & 71 \\
\hline P49125 & 7.6 & 6.9 & 3.4 & 0.91 & 0.45 & 77 & 70 & 85 & 62 \\
\hline P49126 & 6 & 5 & 2.4 & 0.83 & 0.40 & 58 & & & 66 \\
\hline P49127 & 5.5 & 4.6 & 2.1 & 0.84 & 0.38 & 67 & & & 76 \\
\hline
\end{tabular}


v. 2001 Oligoptycherhynchus? hexatoma; García-Alcalde, fig. 2.

v. 2015 Oligoptycherhynchus? aff. hexatoma; García-Alcalde, p. 55, fig. 7 .

Derivatio nominis. Species dedicated to Francisco Javier Álvarez Pulgar, Emeritus Professor of the University of Oviedo, close colleague and lovely friend, as a tribute to his extraordinary research work.

Material. More than four hundred, mainly bivalved, numbered specimens, in fair to good conditions, coming from the type locality (Figs. 1-3). One hundred, unnumbered, heavily crushed and broken specimens from other Asturian localities (especially from Moniello cove, Luanco, Asturias, coming from almost all the levels sampled therein between levels M816 and M916 of Méndez-Bedia, 1976). Holotype DPO 49103 (Fig. 4a-f), thirty-eight paratypes, DPO 49090-49102, 49104-49127 (Figs. 4-6) and 49294 (sectioned, Fig. 9), forty-five relatively well-preserved topotypes, DPO 49128-49172 (Figs. 6-8), and one hundred and twelve poorly preserved topotypes DPO 49173-49293 (49275, 49185, and 49231 sectioned; Figs. 10-11 A-B respectively) coming from the stratotype. Fifteen specimens, DPO 39813-39817 and 49284-49293 from the Noval Quarry, north of the type locality (Figs. 2-3).

Type locality and stratotype. Path, on the northern edge of a large doline, north of Les Areñes village, Ferroñes, municipality of Llanera, Asturias, which runs near the local road LL-2 (Posada de Llanera-Arlós) (Fig. 2). Limestones belonging to the Moniello Formation (latest Emsian to early Eifelian) cropping out in the doline. The best outcrop is about 725 m NNE of Les Areñes, in the Noval quarry (Fig. 2), with some discontinuities towards the bottom and to the top of the formation. The stratotype, bed A-175 (Fig. 3), is a gray argillaceous, partially dolomitized, limestone bed that occurs in the Lower Member of the formation. The age of the stratotype, according both the fauna (Méndez-Bedia, 1976) and the stratigraphic correlation with the Moniello cove succession, would correspond to the final part of the serotinus conodont Zone (García-López in GarcíaLópez \& Bastida, 2002; García-Alcalde, 2015).

Diagnosis. Adult specimens sub-triangular to subpentagonal in outline, roughly wider than long, maximum width near mid-length, moderately dorsibiconvex profile, maximum height behind the shell margin. Erect to suberect, narrow beak, with an acute apical angle, commissures strongly crenulated with marginal spines. Ventral sulcus and dorsal fold weakly developed, starting near mid-length, coinciding with an intra-neanic shell discontinuity indicated by a strongly marked growth line; moderately high tongue of trapezoidal outline; twenty-one to twenty-six simple, angular, radial costae starting from the beaks, average median costal formula $6 / 5$.

Description. Shell astrophic, sub-triangular to subpentagonal in outline, small size (average length: 12.2 $\mathrm{mm} ; \mathrm{n}=178$; maximum length: $17 \mathrm{~mm}$ ), something wider than long (average width/length: 1.07; $n=177$ ) (Tab. 1), ventribiconvex in juvenile to moderately dorsibiconvex in adult shells profile (dorsal valve up to three times higher than the ventral one in ephebic specimens), medium thick (average thickness/length: 0.55 ; $n=168$ ) (Tab. 1), with the maximum height behind the anterior margin of shell at the last tiers of shell, and maximum width something anterior to mid-length (67.2\% of length; $n=101$ ) (Tab. 1). Paries geniculatus, more or less vertical at the anterior and anterolateral margins of the adult shell. Ventral beak almost erect to suberect, with an acute apical angle (average $\alpha$ : $73^{\circ}$, $\mathrm{n}=99$ ) (Tab. 1). Ventral interarea small, narrow, concave, limited by subangular umbonal edges; delthyrium limited by small but massive deltidial plates, separate although tending to be conjoint basally; mesothyrid to permesothyrid, circular foramen. Dorsal beak and dorsal interarea hidden in the delthyrial cavity. Weak, but well-defined ventral sulcus and dorsal fold starting almost at mid-length (average: $47.8 \%$ of length; $\mathrm{n}=97$ ) (Tab. 1), occupying something more than half the width of shell at the anterior margin (average of wsin/w: 0,59; $n=97$ ) (Tab. 1); ventral sulcus concave to smoothly convex; dorsal fold low, flattened or even medially depressed. Anterior commissure uniplicate; moderately high tongue of trapezoidal outline, dorsalto posterodorsally directed in adults (Figs. 4-7). The entire shell is covered by straight, angular, simple costae extending from beaks, with interspaces similar resulting in a zigzag anterior margin; twenty-two to twenty-six ribs on the dorsal valve and twenty-one to twenty-six on the ventral one, with an average median costal formula $6 / 5$ ( $90 \%$ of specimens). The intercostal spaces extend forward in adults in more or less long, marginal spines that fit under the opposite ribs. The ribs bordering the ventral sulcus are slightly stronger than the rest and they show a tendency to set up anteriorly

Figure on next page

Figure 4. Ferronirhynchia pulgari n. gen. n. sp. All specimens from the stratotype. A-E, Holotype DPO 49096, ventral, lateral, dorsal, anterior, and posterior views; the ventral valve is largely colonized by reticulated bryozoans; $\mathbf{F}$, enlargement of the apical region of figure $c$, showing the morphology of the ventral interarea, deltidial plates and foramen; G-K, Paratype DPO 49095, ventral, lateral, posterior, anterior, and dorsal views; L-O, Paratype DPO 49099, lateral, ventral, anterior, and posterior views; $\mathbf{P}$, enlargement of the posterior region of the ventral valve of the figure $m$ showing a reticulate bryozoan colony settled in the umbonal region; Q-R, Paratype DPO 49092, ventral and lateral views of a specimen profusely colonized by epizoans, mainly reticulate bryozoans; S-T, Paratype DPO 49094, ventral and lateral views of a specimen largely colonized by reticulate bryozoans; scale bar $=5 \mathrm{~mm}$, greater bar only for figures $\mathbf{F}$ and $\mathbf{P}$. 


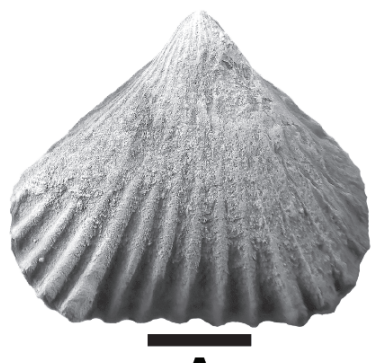

A

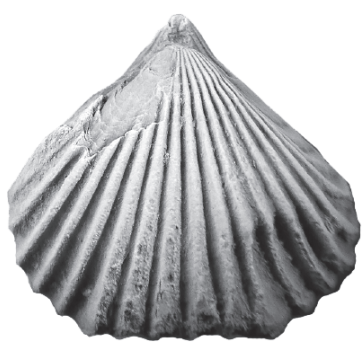

C

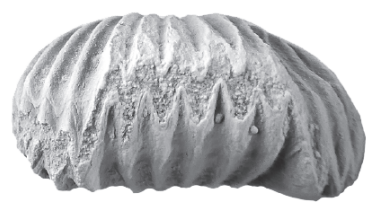

D

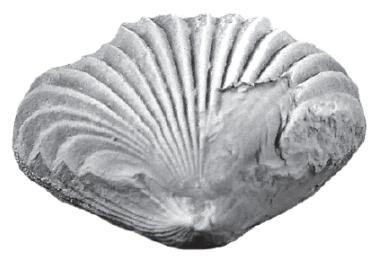

E

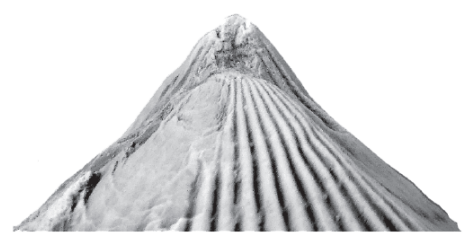

F

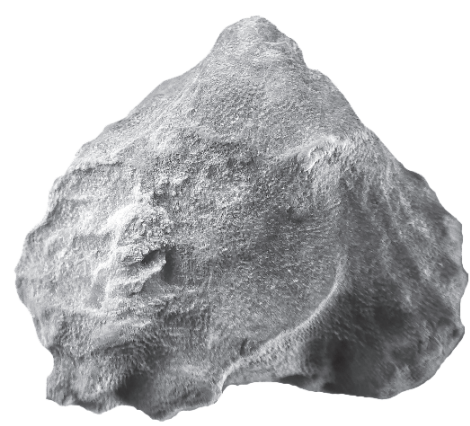

Q

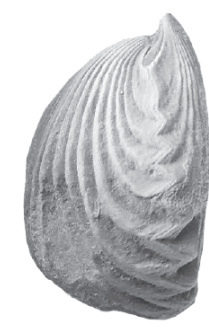

B

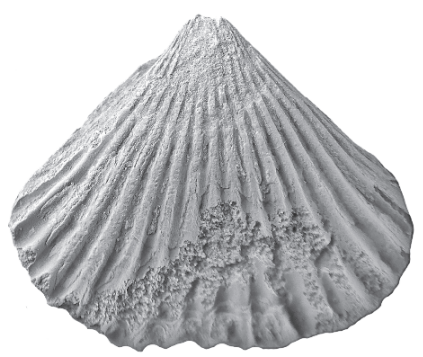

G
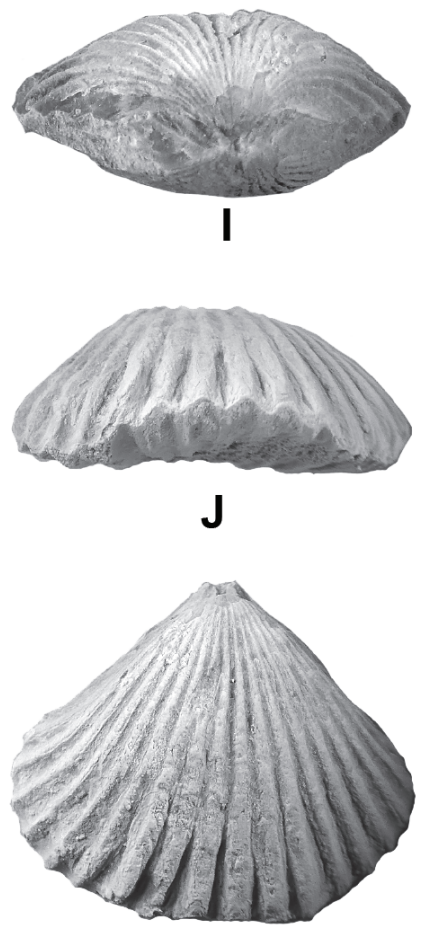

K

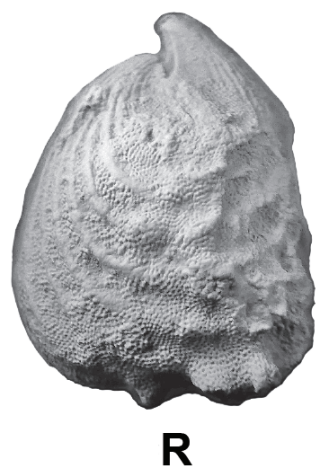

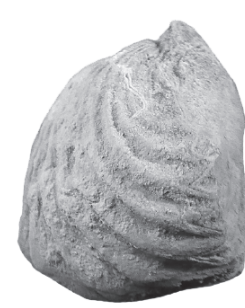

L

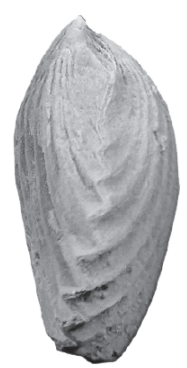

H

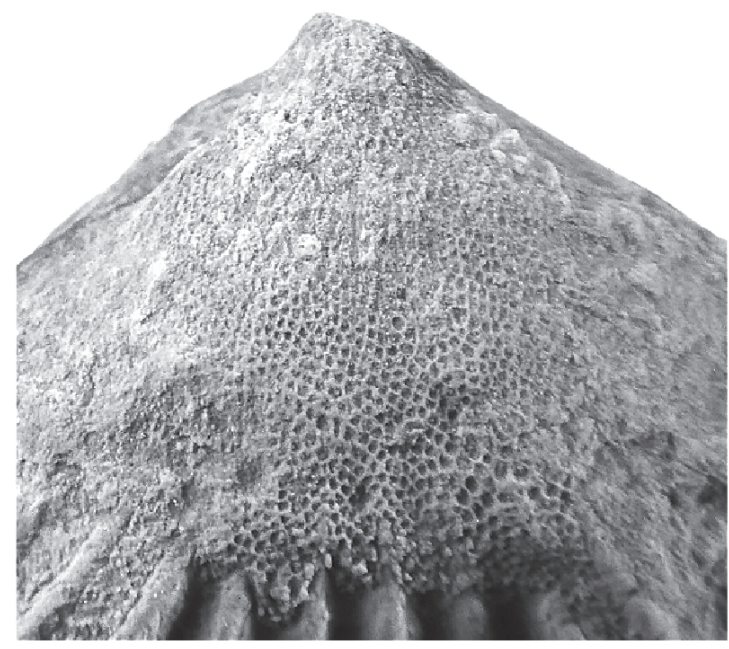

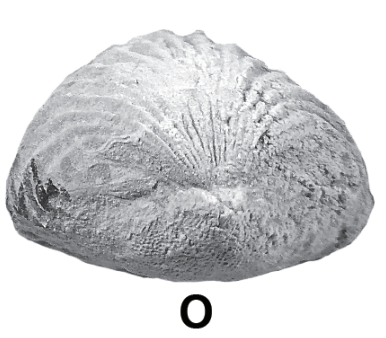

P

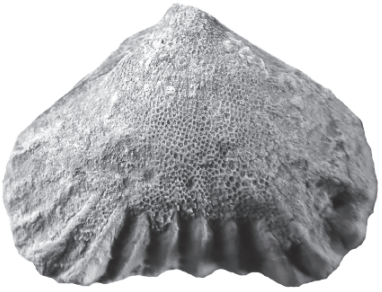

M

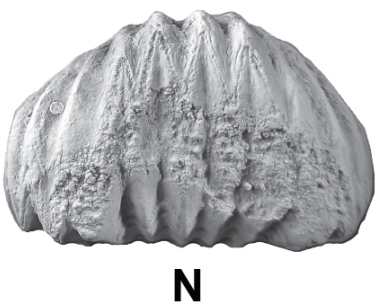

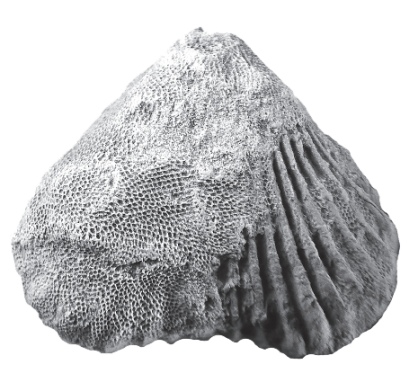

S

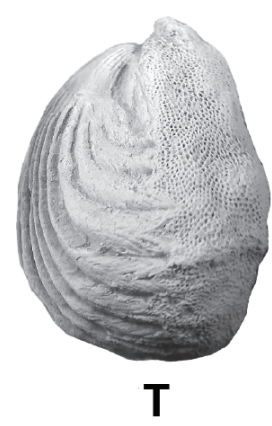




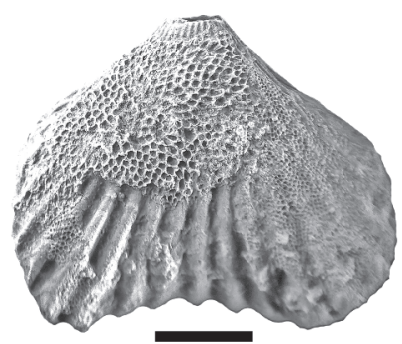

A

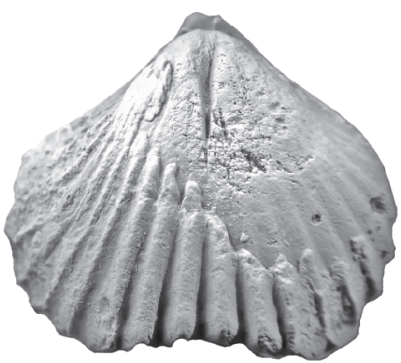

B

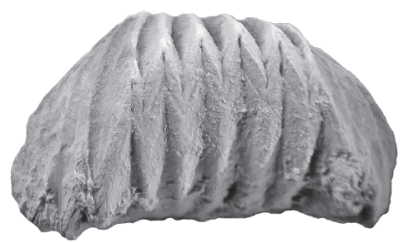

C

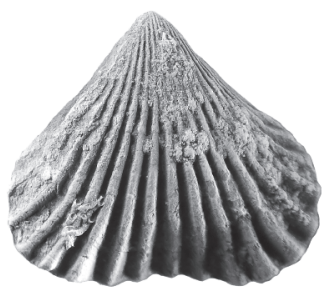

M

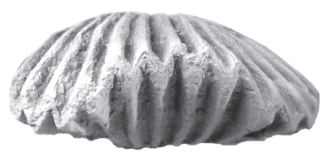

P

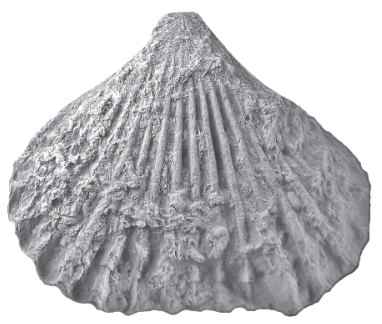

D

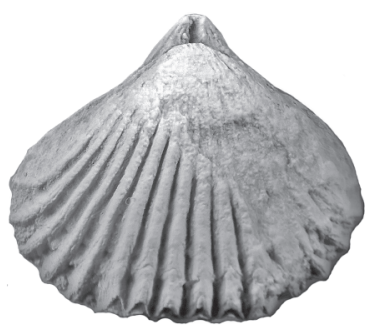

E

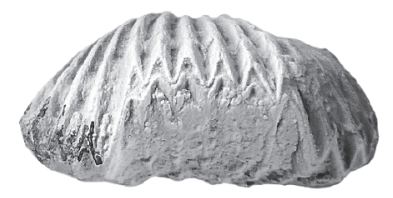

F

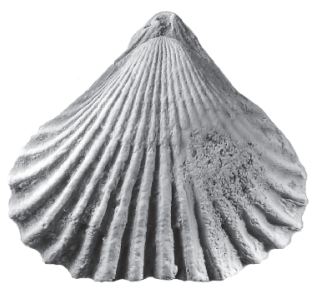

N

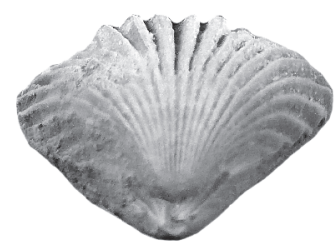

Q

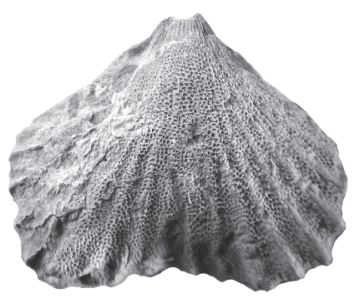

G

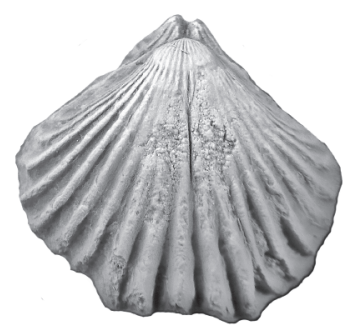

H

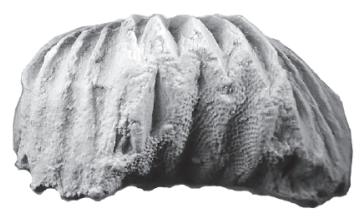

I

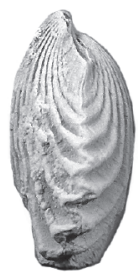

0

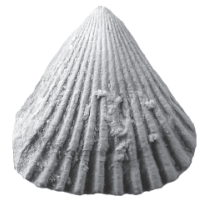

R

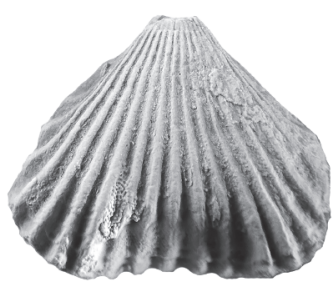

J

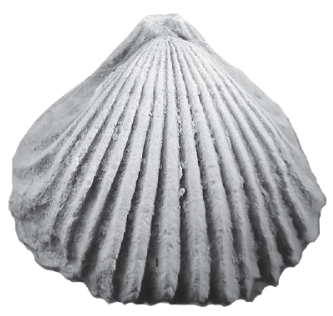

K

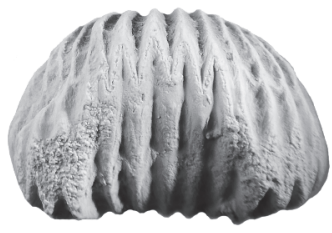

L

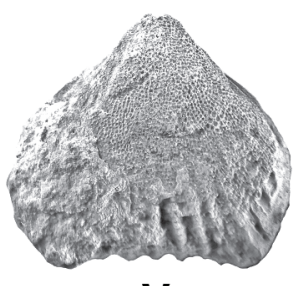

v

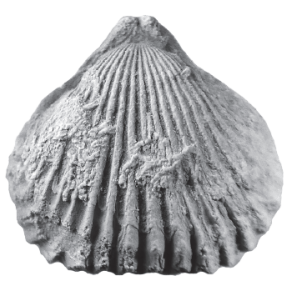

W

Figure 5. Ferronirhynchia pulgari n. gen. n. sp. All specimens from the stratotype. A-C, Paratype DPO 49093, ventral, dorsal, and anterior views of a specimen showing the ventral valve colonized by different types of reticulate bryozoans, and the dorsal valve weakly decorticated showing the trace of a long median septum; D-F, Paratype DPO 49097, ventral, dorsal, and anterior views; ventral valve provided with a narrow interarea, deltidial plates and permesothyrid foramen and profusely colonized by reticulate bryozoans, serpulids and another epizoans; G-I, Paratype DPO 49100, ventral, dorsal, and anterior views; ventral valve provided with a narrow interarea, and well developed deltidial plates, colonized by reticulate bryozoans; dorsal valve weakly decorticated showing the trace of a long median septum; J-L, Paratype DPO 49103, ventral, dorsal, and anterior views; ventral valve showing the trace of marginal spines, and colonized by different epizoans; M-Q, Paratype DPO 49104, ventral, dorsal, lateral, anterior, and posterior views of an early ephebic shell with faintly developed paries geniculatus, very low ventral tongue, permesothyrid foramen and a narrow ventral interarea; R-T, Paratype DPO 49123, ventral, dorsal, and anterior views of a neanic shell with sharp commissures lacking of paries geniculatus and with the dorsal valve slightly decorticated showing the trace of a long median septum; U-W, Paratype DPO 49106, lateral, ventral, and dorsal views of an ephebic specimen with relatively well developed paries geniculatus and with both valves colonized mainly by reticulate bryozoans and auloporid tabulate corals; scale bar $=5 \mathrm{~mm}$. 


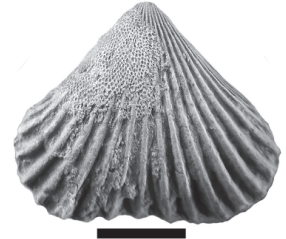

A

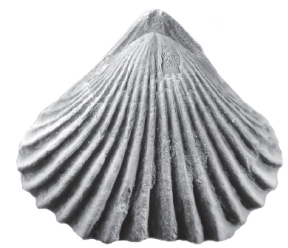

B

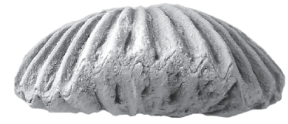

C

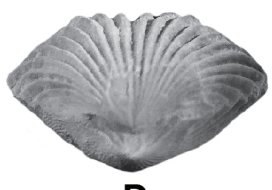

D

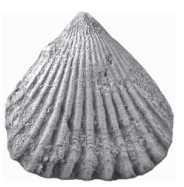

S
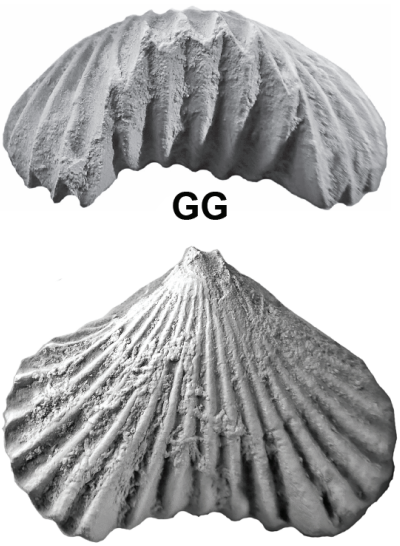

$\mathrm{HH}$

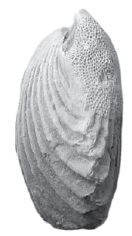

E

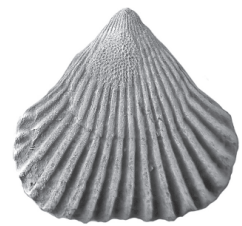

G

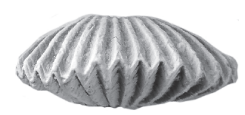

H

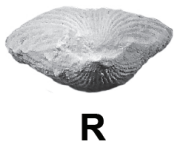

$\mathbf{R}$

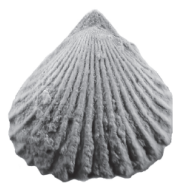

U

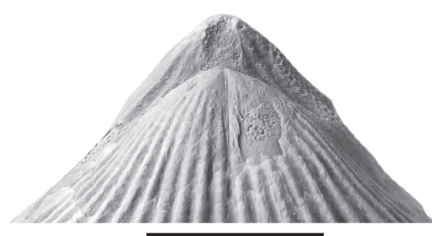

F

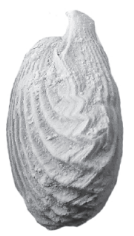

K

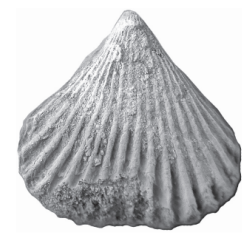

L

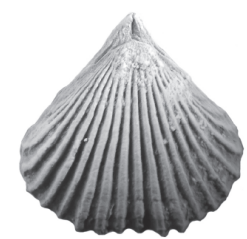

M

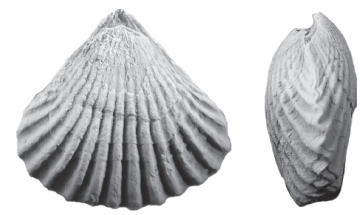

P

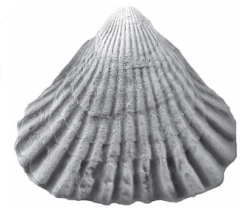

0

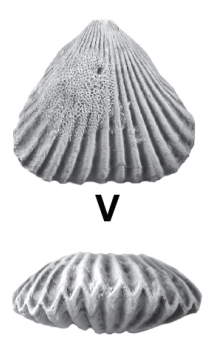

w

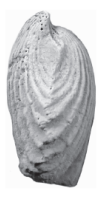

X

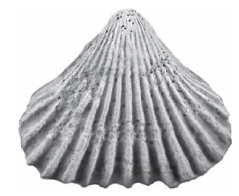

$Y$

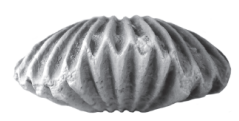

AA

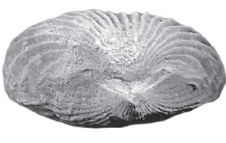

N

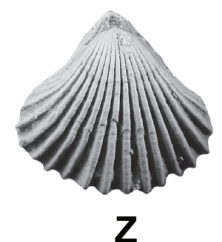

Z

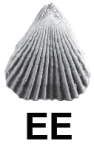

(4i)

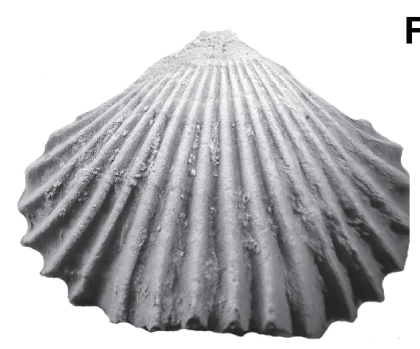

II
FF

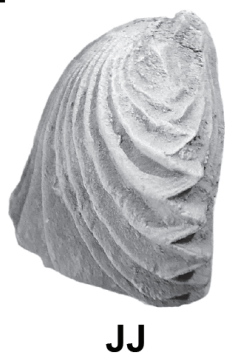

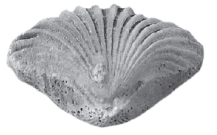

BB

Figure 6. Ferronirhynchia pulgari n. gen. n. sp. All specimens from the stratotype. A-E, Paratype DPO 49107, ventral, dorsal, anterior, posterior, and lateral views of a specimen with the ventral valve partially colonized by epizoans; $\mathbf{F}$, enlargement of the figure $b$ anterior, showing the structure of the apical ventral region; G-J, Paratype DPO 49112, ventral, anterior, lateral, and dorsal views of a shell showing a marked intra-neanic discontinuity at the beginning of the ventral sinus and dorsal fold; $\mathbf{K}-\mathbf{N}$, Paratype DPO 49111, lateral, ventral, dorsal, and posterior views of an early ephebic specimen with weakly developed paries geniculatus; O-Q, Paratype DPO 49113, ventral, dorsal, and lateral views of a shell with the anterior margin corresponding to the intra-neanic discontinuity damaged in life and repaired later; R-U, Paratype DPO 49121, posterior, ventral, lateral, and dorsal views; V-W, DPO 49156, ventral, and anterior views of a specimen showing the ventral valve partially colonized by reticulate byozoans; X-BB, DPO 49154, lateral, ventral, dorsal, anterior, and posterior views of an early ephebic specimen with an incipient tongue, and barely developed lateral paries geniculatus; CC-FF, Paratype DPO 49127, ventral, lateral, dorsal, and anterior views of an early neanic shell lacking ventral sinus; GG-JJ, DPO 49001, anterior, ventral, dorsal, and lateral views of an adult shell showing the ventral valve colonized by auloporoid epizoans; KK-MM, DPO 49170, anterior, dorsal, and ventral views of an early ephebic shell with a weakly decorticated dorsal valve showing the trace of a long median septum; scale bar $=5 \mathrm{~mm}$, greater bar only for figure $\mathbf{F}$. 


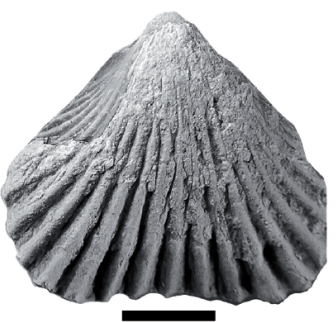

A

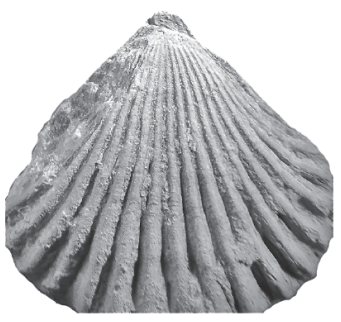

B

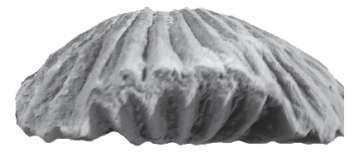

C

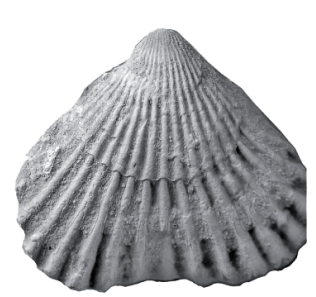

K

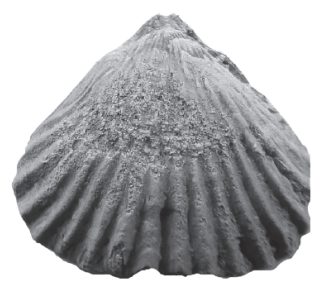

L

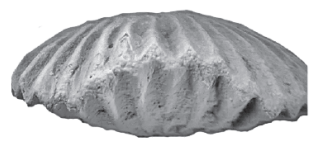

M

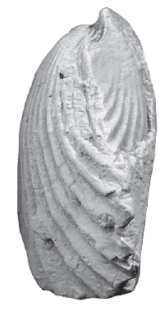

D

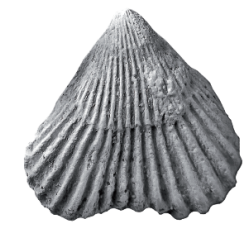

E

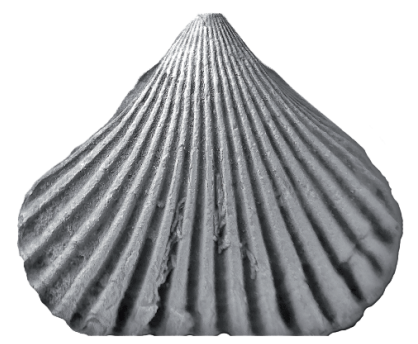

W

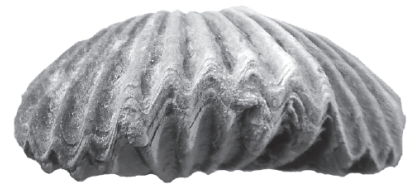

X
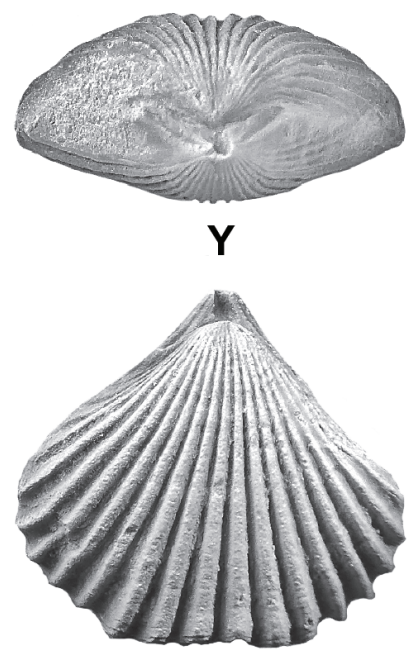

Z

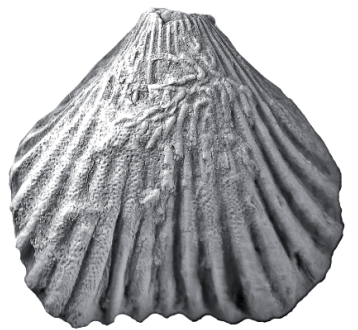

H

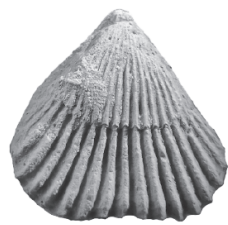

F

G

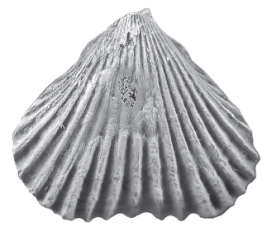

N
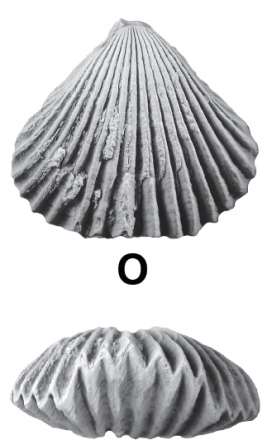

P

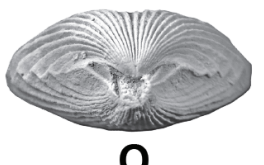

Q

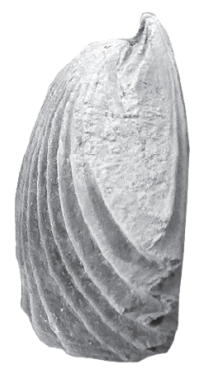

AA

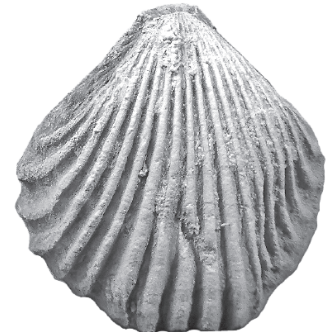

I
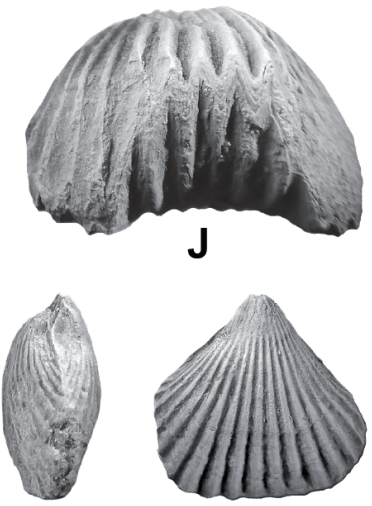

R

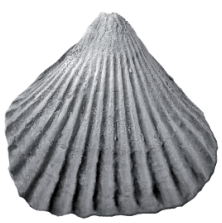

S
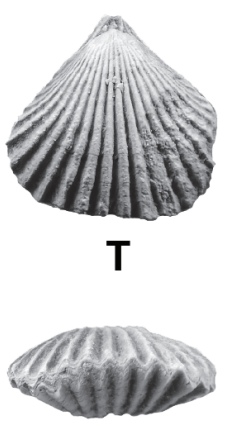

U

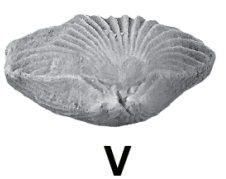

V

Figure 7. Ferronirhynchia pulgari n. gen. n. sp. All specimens from the stratotype. A-D, DPO 49010, ventral, dorsal, anterior and lateral views; E-G, DPO 49069, ventral, dorsal and lateral views of an asymmetrical specimen with a twisted umbonal region, a marked intra-neanic discontinuity, and both valves colonized by epizoans; H-J, DPO 49012, ventral, dorsal and anterior views of a specimen with ventral valve colonized by auloporoid epizoans; K-M, DPO 49048, ventral, dorsal and anterior views of a specimen showing a marked intra-neanic discontinuity in the ventral valve; N-Q, DPO 49145, ventral, dorsal, anterior and posterior views; R-V, DPO 49068, lateral, ventral, dorsal, anterior and posterior views; W-AA, DPO 49019, ventral, anterior, posterior, dorsal and lateral views; BB, enlargement of the ventral umbonal region of the figure $\mathbf{z}$, showing the morphology of the ventral interarea and the development of the deltidial plates; scale bar $=5 \mathrm{~mm}$, greater bar only for figure BB. 


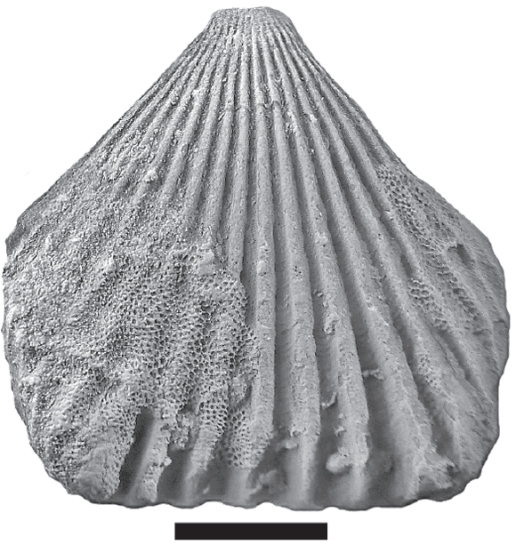

A

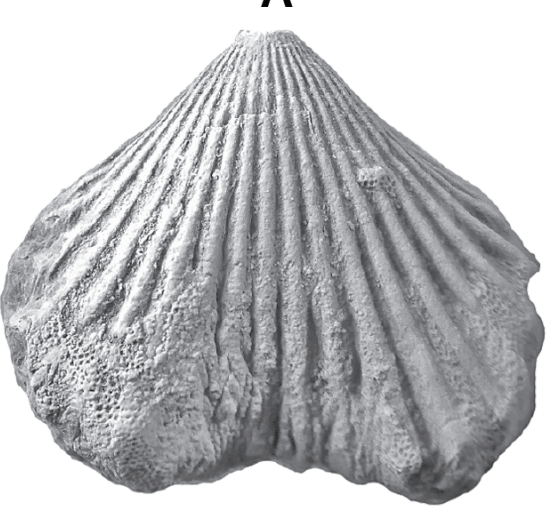

B

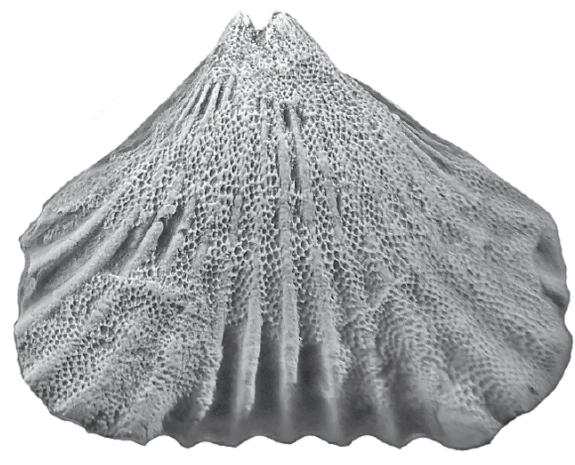

D

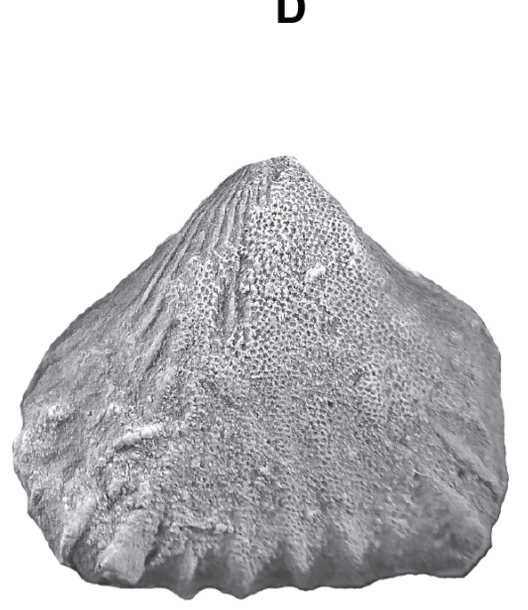

E

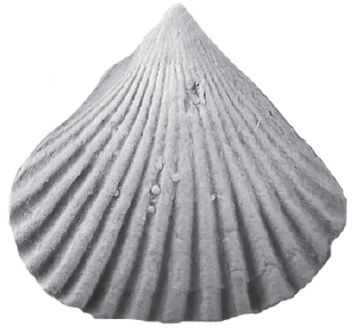

F

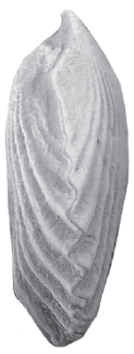

G

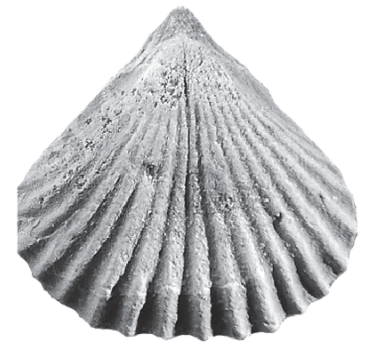

H

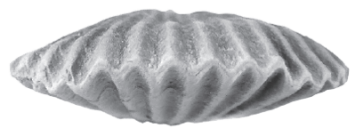

I

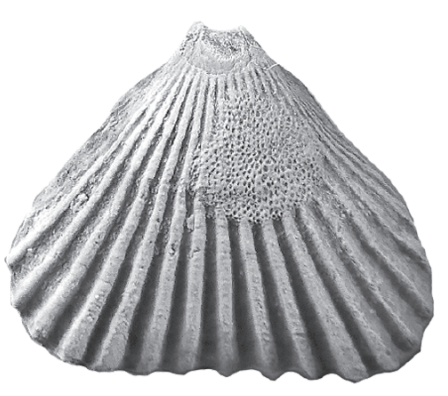

C

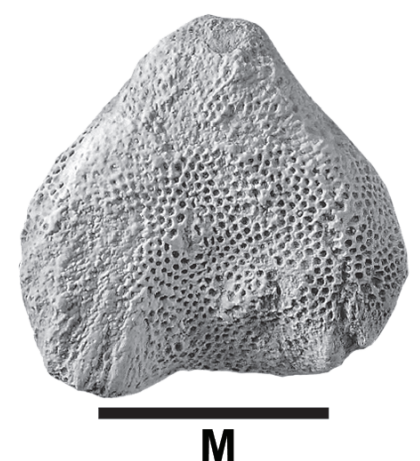

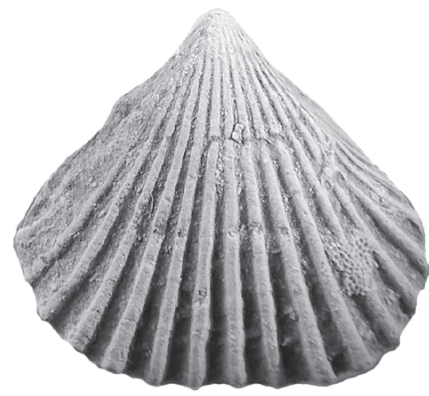

J

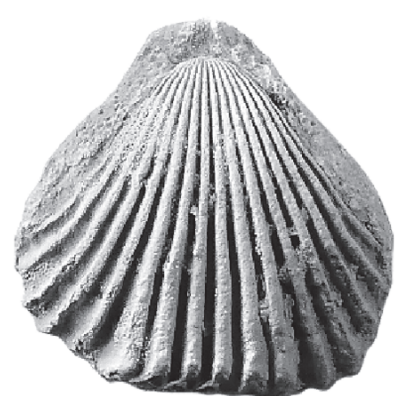

$\mathbf{N}$

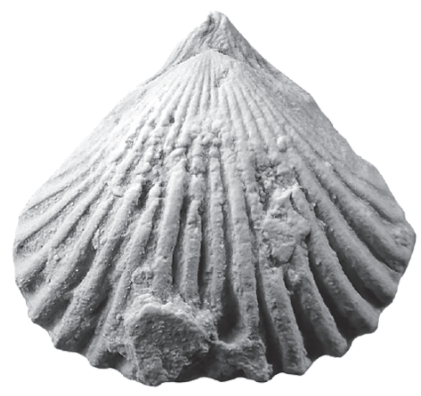

K

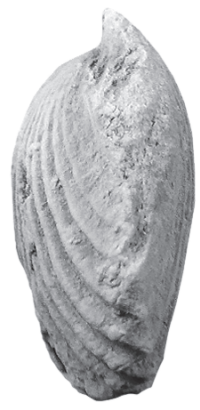

L

Figure 8. Ferronirhynchia pulgari n. gen. n. sp. All specimens from the stratotype. A, DPO 49132, ventral valve partially colonized by reticulate bryozoans and other epizoans; B, DPO 49135, ídem; C, DPO 49149, ídem; D, DPO 49134, ídem; E, DPO 49138, ídem; F-I, DPO 49157, ventral, lateral, dorsal and anterior views of a young specimen with a something decorticated dorsal valve showing the trace of a long median septum; J-L, DPO 49152, ventral, dorsal and lateral views of a specimen with both valves colonized by epizoans; M-P, DPO 49197, ventral, dorsal, anterior and posterior views of a specimen with the ventral valve entirely colonized by reticulate bryozoans; scale bar $=5 \mathrm{~mm}$, greater bar only for figures $\mathbf{M}-\mathbf{P}$. 
0.1

1.2

1.4

1.8

2

2.2
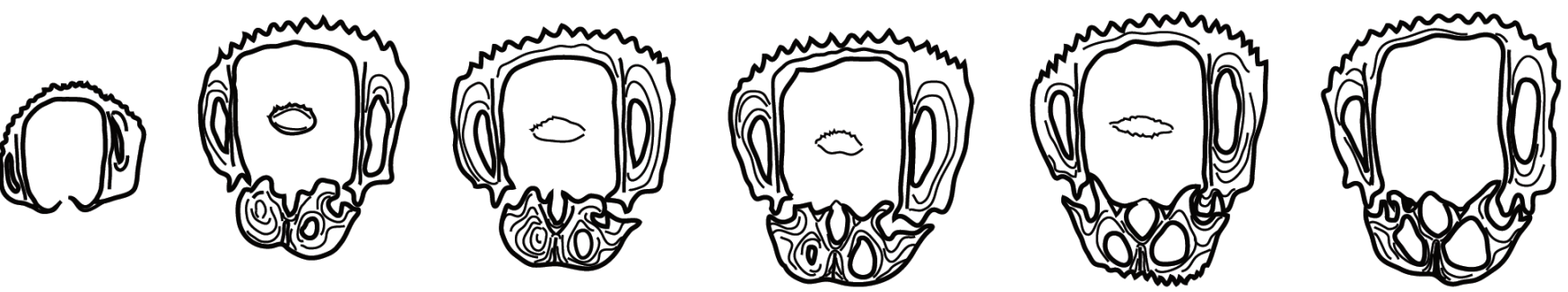

2.7

3

3.6

3.7

3.9
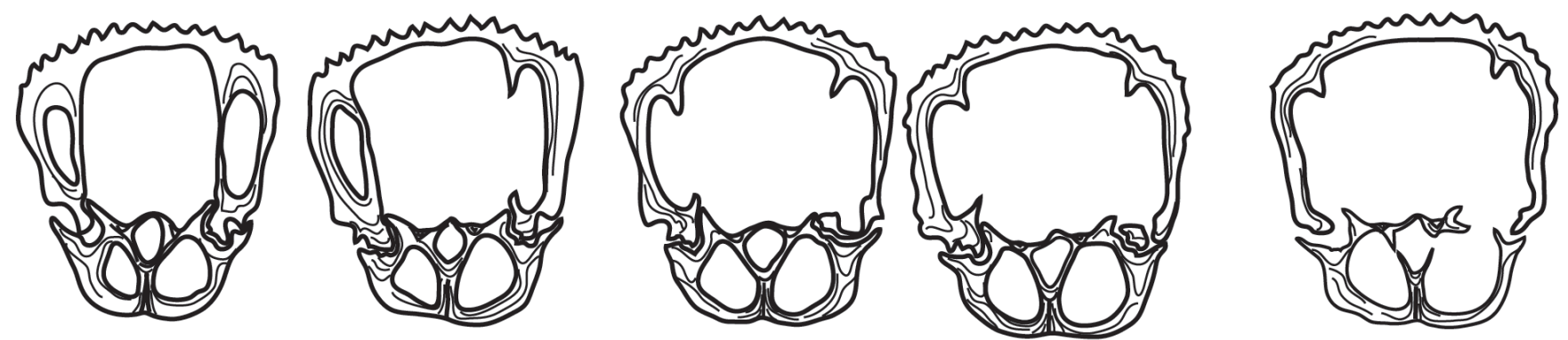

4.1

4.4

4.5

4.7

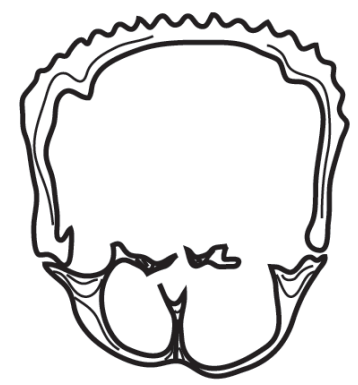

4.9

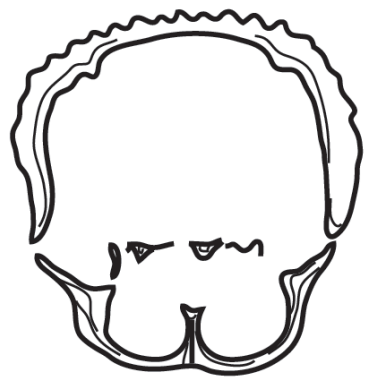

5.1

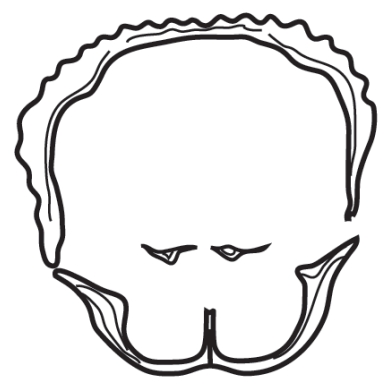

5.3

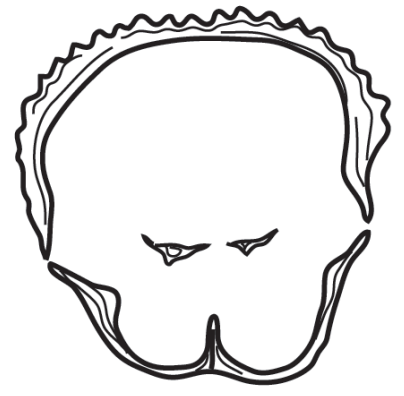

5.6
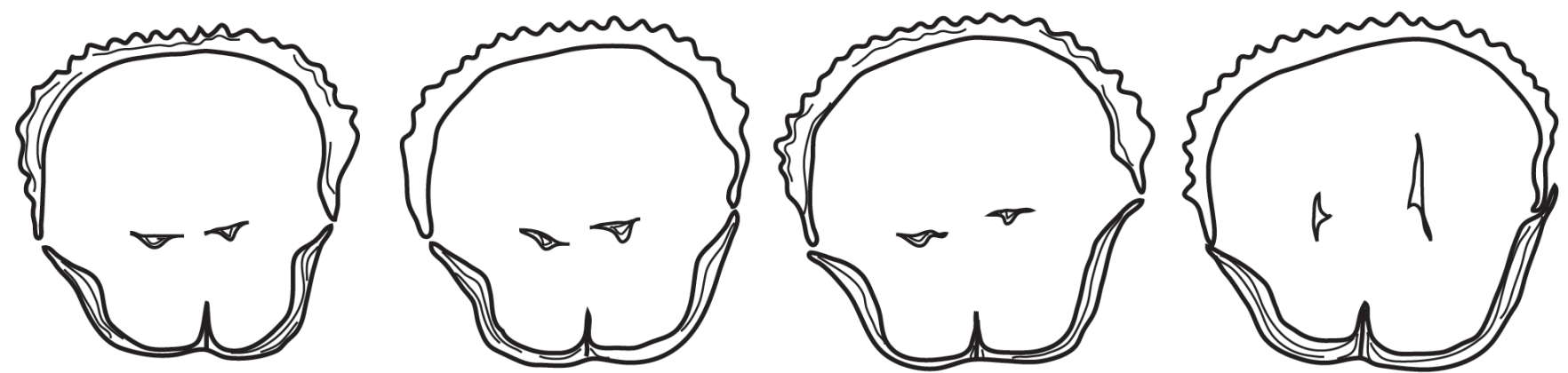

5.7

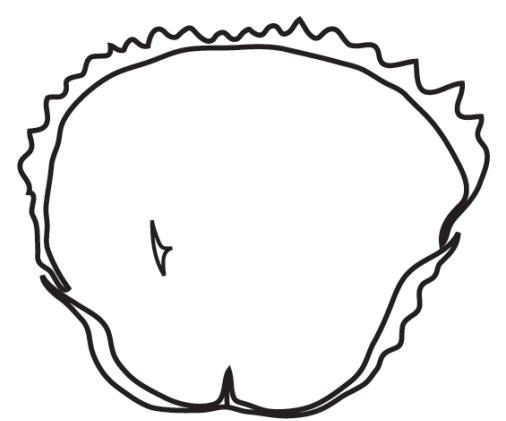

Figure 9. Ferronirhynchia pulgari n. gen. n. sp. Paratype DPO 49294. Serial sections perpendicular to both the commissural and the symmetry planes. Heading figures: distances of the sections to the ventral apex in $\mathrm{mm}$. Sections 1.2 and $2 \mathrm{~mm}$ integrate likewise sections of a smaller shell, perhaps a neanic specimen of the same species introduced post-mortem into the delthyrial cavity of the older shell; scale bar $=5 \mathrm{~mm}$. 

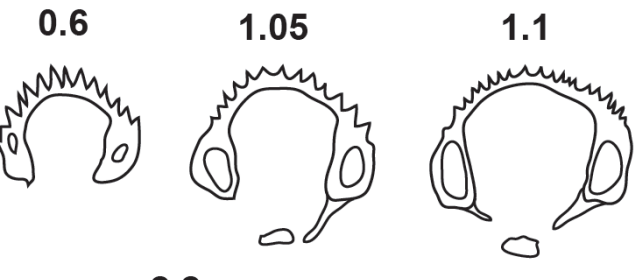

2.2

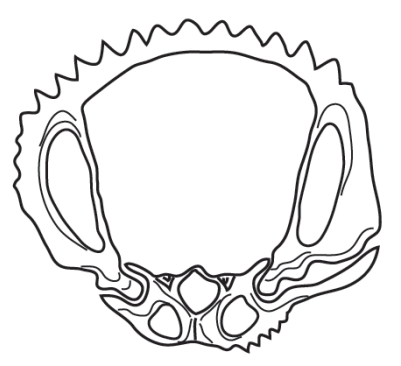

2.65

1.3

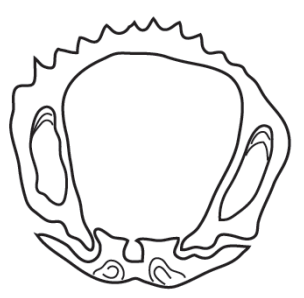

2.75

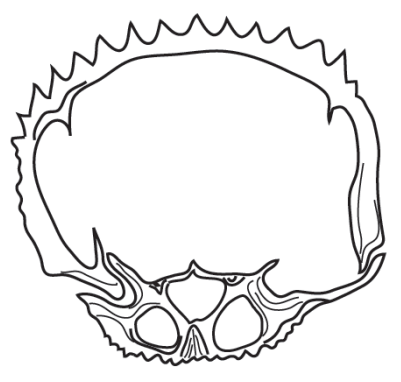

3.05

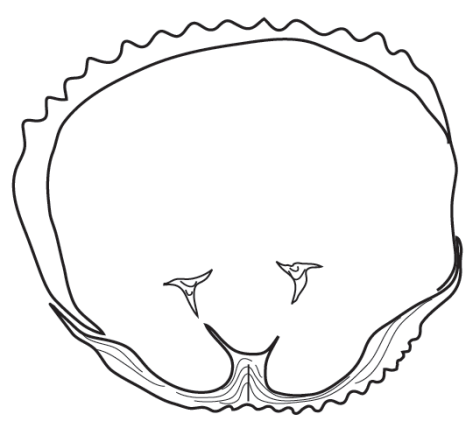

3.2

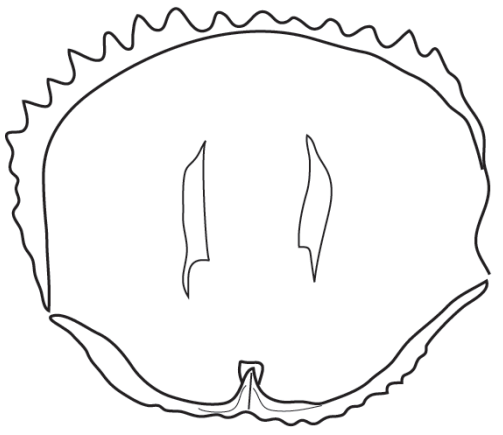

3.6

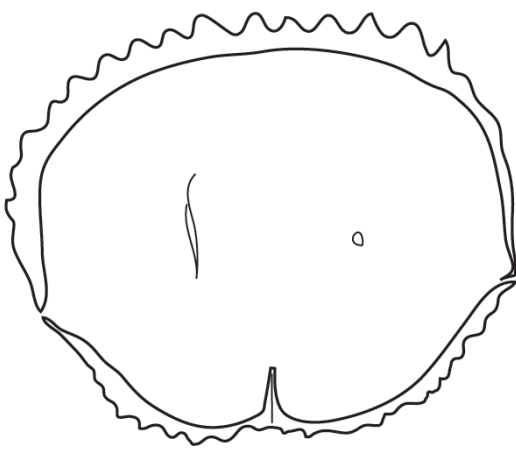

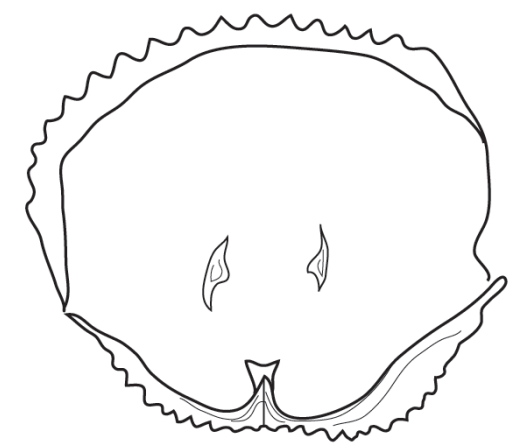

3.4

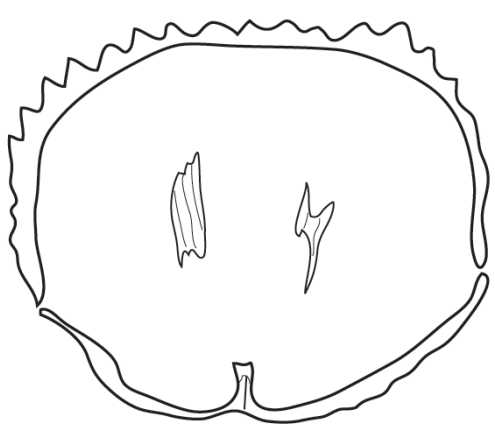

3.65

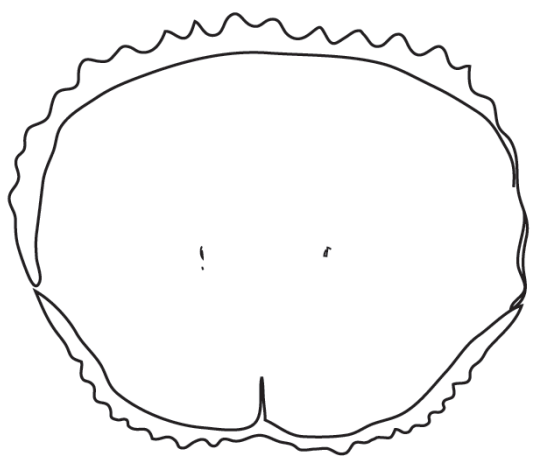

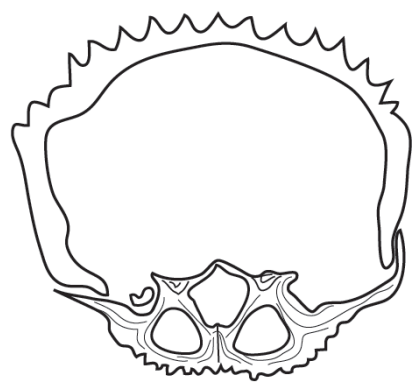

1.75
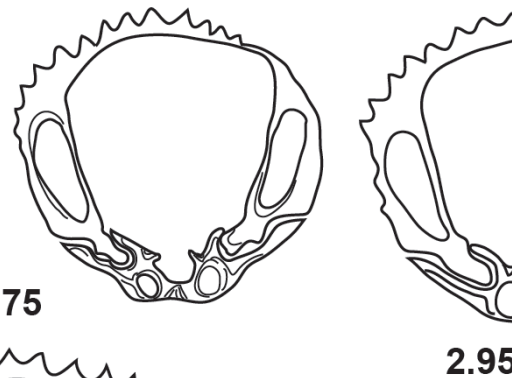

2.95

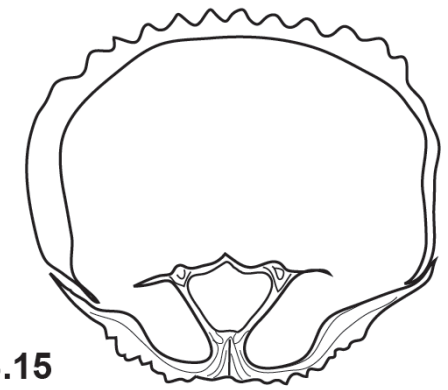

3.15

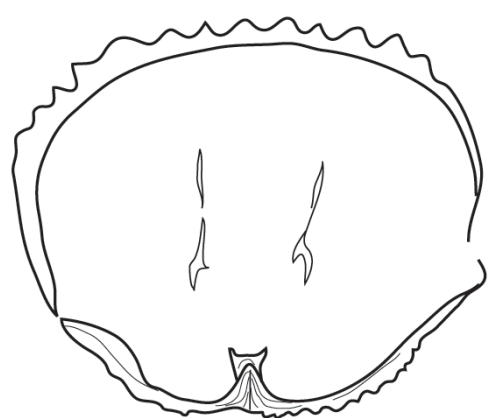

3.55
2.15

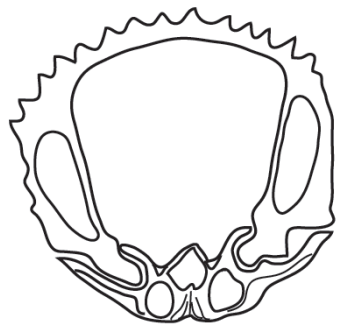

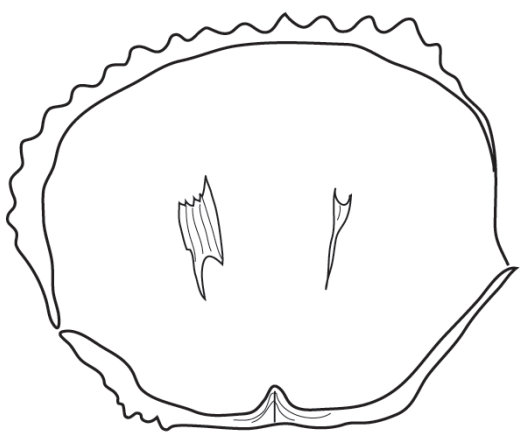

Figure 10. Ferronirhynchia pulgari n. gen. n. sp. DPO 49275. Serial sections perpendicular to both the commissural and the symmetry planes. Heading figures: distances of the sections to the ventral apex in $\mathrm{mm}$. Exceptionally, the dental plates of this specimen converge towards the dorsal valve; scale bar $=3 \mathrm{~mm}$. 


\section{$0.5 \quad 0.65$ \\ 1.3 \\ 20

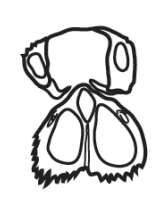

2.5
2.6
1.35

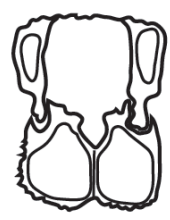

2.8
1.7

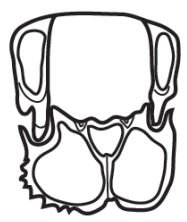

2.85
1.8

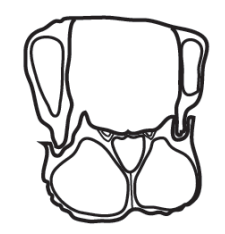

2.05
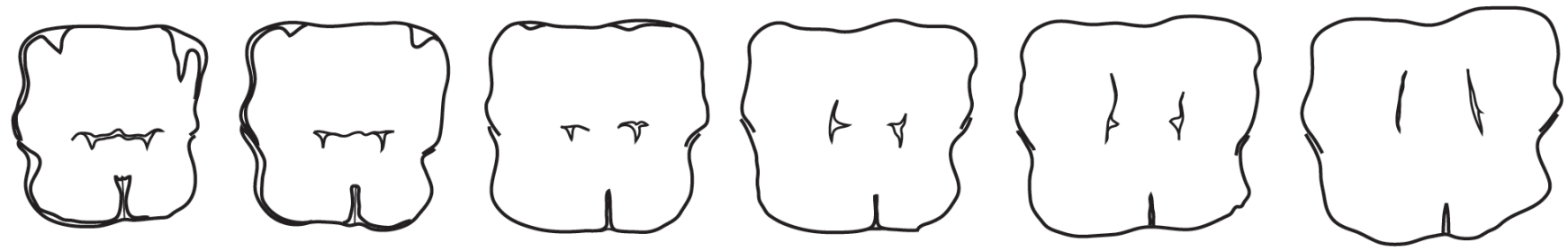

3.6
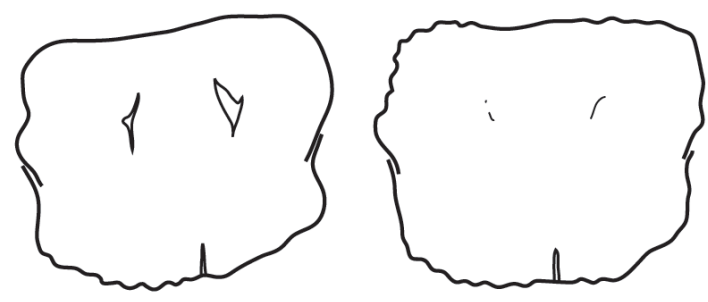

A
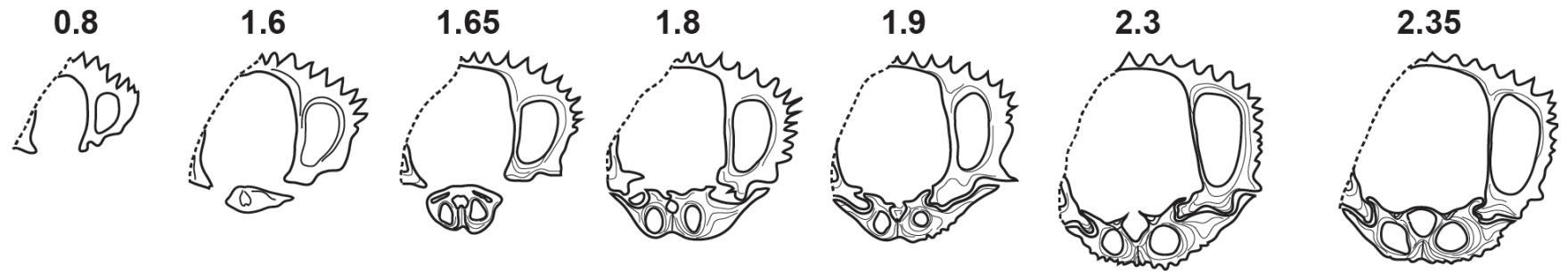

2.55

2.6

2.9

3.1

3.2

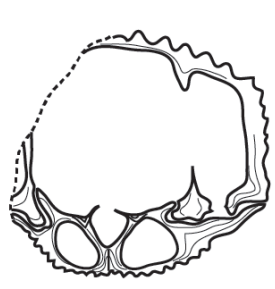

3.45

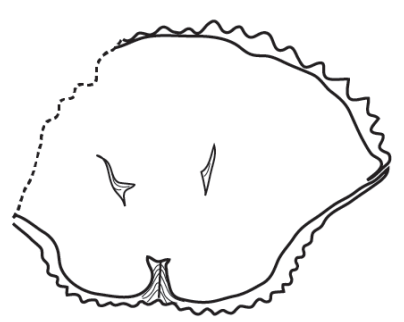

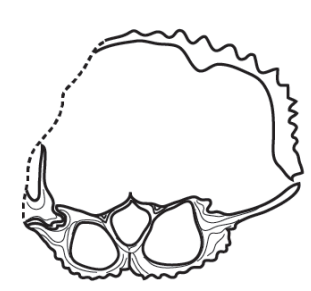

3.5

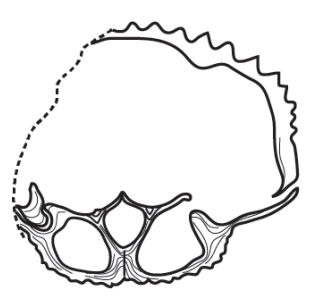

3.7

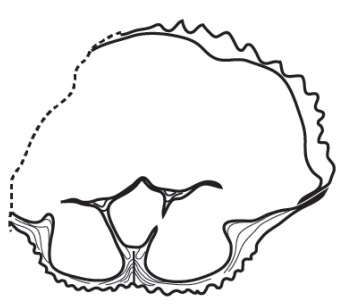

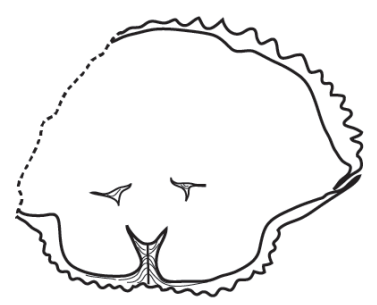

4.1
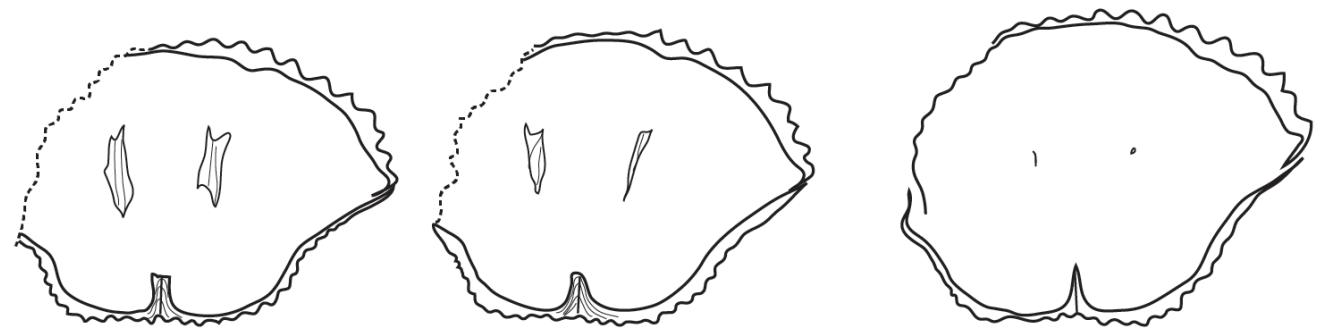

B

Figure 11. Ferronirhynchia pulgari n. gen. n. sp. Serial sections perpendicular to both the commissural and the symmetry planes. A, specimen DPO 49231; B, specimen DPO 41185, weakly damaged on the left side of the ventral valve. Heading figures: distances of the sections to the ventral apex in $\mathrm{mm}$; scale bar $=3 \mathrm{~mm}$. 
in parietal position on the sulcus walls, lower than the next lateral pair; the ribs on both the ventral sulcus and the dorsal fold are weakly asymmetrical with longer slopes extending towards the symmetry plane or towards the flancs of the valve, respectively. The shell surface shows one or two very obvious and distant growth lines, the most important one coinciding with the starting point of the ventral sulcus and the dorsal fold at the boundary early/late neanic growth stages (see later). The paries geniculatus of adult shells shows slightly more rounded and lower ribs than the rest of shell, ornamented by numerous very fine growth lines. The umbonal margins lack ribs and form more or less developed, flattened and narrow lunular surfaces (planareas) from which the commissures become crenulate. Weakly excavated muscle scars almost imperceptible on decorticated shells. Well-developed squamae and glottae (Figs. 9-11). Parallel to weakly convergent, long and relatively thick dental plates well separated from the shell wall, defining relatively narrow, open umbonal chambers (Figs. 9-11). The dental plates support strong, usually somewhat crenulate, cardinal teeth; the teeth bases are weakly excavated in crural fossettes to accommodate the distal ends of high, ventro-laterally directed inner socket ridges (Figs. 9-11). Well-developed, sometimes crenulate dental cavities (Figs. 9, 11B). The cardinal platform tilts somewhat dorsally; two crural plates extend middorsally from the platform until they join a strong but not very high median septum, defining a great, cupuliform septalium. The septalium is open proximally but in a great part covered by a tectiform connectivum formed by thin extensions towards the plane of symmetry of the crural bases (Figs. 9-11). Radulifom crura with T-shaped sections extended to a short distance in front of the cardinal platform at the same plane and then bending antero-ventrally into vertical lamellae (Figs. 9-11). The median septum becomes thinner and sharper forward, until it disappears near mid-length or even beyond (Figs. 9-11); the median septum shows a clear axial median granular calcite sheet with lamellae of secondary shell on both sides (viz. a true dorsal septum, Figs. 9-11).

Ontogeny. The earlier stages of development, protegular and brephic (prior to the appearance of the radial ornamentation) are not preserved in the available specimens, or they are not evident at all. The neanic (juvenile) phase, on the other hand, is quite well visible in the studied specimens. Young shells are predominantly equidimensional or somewhat longer than wide, subtriangular in outline, with maximum width near the anterior margin, very low, biconvex to ventribiconvex profile (concha plana stage, Westbroek, 1967), with the surface of the ventral valve regularly convex, but with the dorsal one weakly depressed medially, and maximum height posterior to half length of the shell, sharp, crenulate commissures and acute, almost erect ventral beak (Figs. 5-6). As the growth in length progresses, in almost $50 \%$ of specimens the ventral sulcus and dorsal fold start at a distance between 3.5 and $5 \mathrm{~mm}$. This usually coincides with the occurrence of a marked discontinuity, which is evident by a prominent growth line. This is a diagnostic and unique feature of the species unknown in closely related forms. The shell growth continues from the discontinuity maintaining the flatly biconvex profile and sharp commissures along a late neanic interval, until a point where the margins of valves bend suddenly towards each other, starting the formation of progressively taller, vertical paries geniculatus. This event initiates the geniculate, ephebic stage. The occurrence of abrupt flanks, and a ventral tongue turning distally at right angles towards the dorsal valve, is characteristic of the concha alta adult stage (Westbroek, 1967), in which marginal spines interlaced in a dense grid develop (Westbroek, 1967; García-Alcalde, 2009; García-Alcalde \& Herrera, 2015). The shell length in adults is highly variable (Fig. 12, Tab. 1) giving the impression that the shells might have been able to keep growing forward after the formation of the paries geniculatus, which is difficult to explain. Analyzing the growth of other rhynchonellid geniculated forms, such
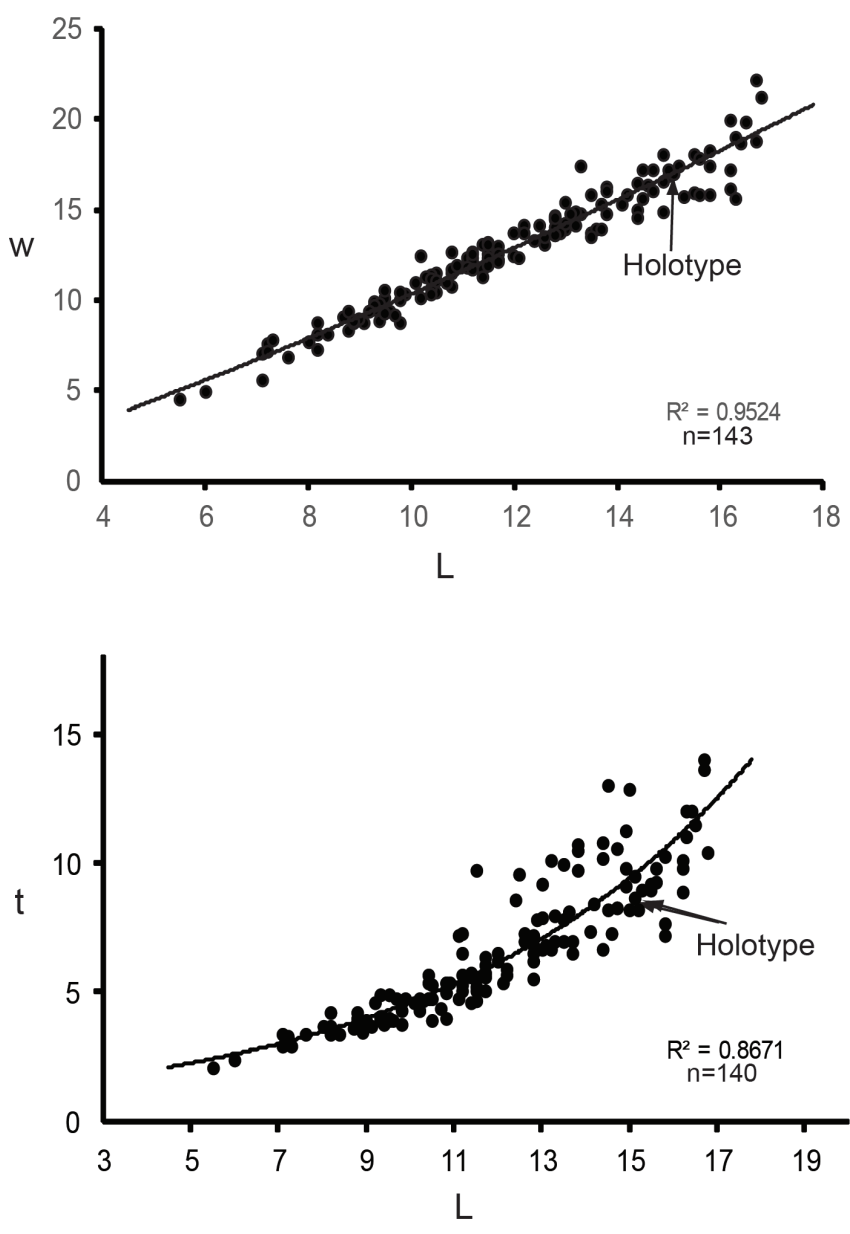

Figure 12. Length/width (L/w) and length/thickness (L/t) dispersion diagrams of the Ferronirhynchia pulgari $\mathrm{n}$. gen. $\mathrm{n}$. sp. assemblage gathered in the species stratotype, Les Areñes North Doline, locality A-175. 

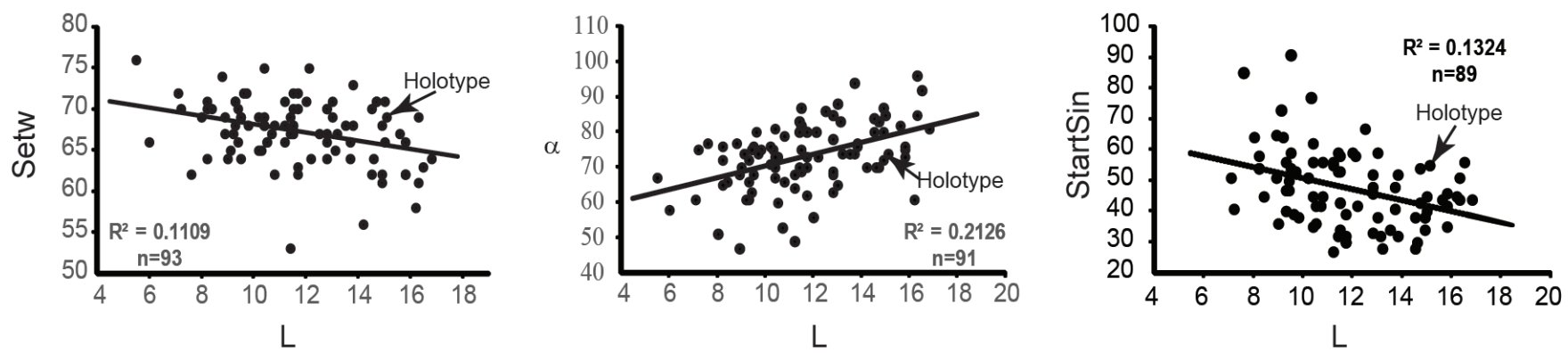

Figure 13. Length, with respect to the setting of the maximum width (Setw), the apical angle ( $\boldsymbol{\alpha})$ and the beginning of the ventral sinus (StartSin) scatter diagrams.

as Uncinulidae, Schmidt (1937) proposed a polycyclic process during which individuals could dissolve, in each cycle, the paries geniculatus already formed. After that, the individual would grow somewhat longer for a limited period developing new paries geniculatus taller and longer than the previous ones. Such a complex mechanism was contested by Schumann (1965) and Westbroek (1967). However, the actual process by which geniculate forms grow producing a great variability of shapes and sizes has not been explicitly stated by previous authors. Tentatively, it is proposed here that there must have had a prior wide-length variability among late neanic forms; this could result in the co-occurrence of both short, fully geniculate, morphological mature shells, and long, biconvex, with sharp commissures morphological immature shells in a given time near the neanic/ephebic transition development stage. In any case, while juvenile shells tend to increase in thickness proportionally with age, they continue with an allometrical growth as adults. At this stage the main (or the only) growth component was in height as shown in Figure 12. There are other growth tendencies, usually poorly expressed, in Ferronirhynchia pulgari. For example, the position of the maximum height that moves forward in neanic forms without, however, reaching the anterior margin. Or the shell outline that tends to become sub-pentagonal, looking as the maximum width was moving further and further backwards (Fig. 13). Juvenile shells, especially the early neanic ones, look more pinched posteriorly than late neanic and ephebic shells. These younger specimens have suberect to erect beaks and acute apical angles, while more aged specimens show more incurved beaks with apical angles approaching $90^{\circ}$ (Fig. 13). Finally, the ventral sulcus origin also looks as receding in position with age (Fig. 13). This is an intuitively surprising phenomenon, which could also be explained by the wide size variability in neanic shells or, alternatively, by post-mortem deformation.

Paleoecological remarks. Ferronirhychia pulgari is, by far, the dominant species of the association where it is found. It forms parautochthonous assemblages consisting of complete and articulated shells, including all postbrephic development stages and without recognizable signs of post-mortem transport. This implies that fossil assemblages are close to the original populations, without substantial taphonomic alterations. Therefore, this supports a robust taxonomic characterization of the species. F. pulgari assemblages dominated in calm, low-energy settings, most likely in areas sheltered by small reefs. The dominant clayey composition of the rocks in which they occur supports this interpretation. The Ferronirhynchia pulgari stratotype as well as the immediately under- and overlying beds (Fig. 3), was deposited during one of the small transgressiveregressive cycles first mentioned in Méndez-Bedia (1976) and Arbizu et al. (1979) and described in detail by García-Alcalde (2015). They occur in the lower and middle members of the Moniello Formation, particularly during the cycle stage c (García-Alcalde, 2015, p. 46) characterized by packstones-wackestones and interbedded shale layers. That environment was located below the wave-base level, in conditions of low oxygen content and nutrient supply. This would favour the existence of a few medium-sized species, mainly solitary corals of the so-called "Cyathaxonia Fauna" and other opportunistic forms such as F. pulgari. Muddy sedimentation (Fernández et al., 1996) and limited food resources made this kind of organisms very usable substrates for a multitude of small encrusting organisms: bryozoans, auloporids, serpulid and other tubeworm organisms that would otherwise have died buried in the fine sediment. The epizoans located mostly at the commissures of brachiopods indicate that the colonization took place when the hosts were still alive. Therefore, the epizoans would take advantage of part of the food particles in suspension captured by the brachiopod inhalant currents and/or of recyclable fractions of the feces ejected by the exhaling currents. Near half of the typical population of F. pulgari was colonized by encrusting organisms (Figs. 4-8) even by two or more overlapping epizoan generations. This suggests an intense competition among encrusters for the available space. It seems that the epizoans had not a negative effect on F. pulgari; so that, the relations between hosts and colonists would be rather commensalist, even mutualistic, with epizoan forming a protective masking covering the host shell when they were alive. Eventually, the excessive epizoan 
proliferation, especially of reticulate bryozoan colonies, almost completely enclosed the brachiopod shell. In these particular cases, it cannot be ruled out that the dense colonization by encrusters disabled blocked the opening of the valves leading to suffocation death of the hosts. Alternatively, it could also be a question of postmortem colonization. Most brachiopods (> $75 \%$ of the specimens) show epizoans on the ventral valves and $15 \%$ show encrusters on both valves. This suggests that the living position of the brachiopods would be with the ventral valve above, with the shell standing out from the substrate. The fact that a significant number of hosts were encrusted from the very apex of shell, and the slight curvature of beak indicate that $F$. pulgari had a fully functional pedicle, even in the adult stages. This, in turn, allowed movements of the shell above the sediment level and, consequently, its early colonization.

\section{DISCUSSION}

Ferronirhynchia pulgari n. gen. n. sp. was earlier interpreted by the author as belonging to Oligoptycherhynchus hexatomus (Schnur, 1851) (Terebratula hexatoma Schnur, 1853, p. 176, Tafel XXII, fig. 2a-e non 2f, g). Ferronirhynchia pulgari resembles $O$. hexatomus in: the number, shape and arrangement of costae, but the latter species differs in: 1) a strongly dorsibiconvex profil with maximum height at the anterior margin of the shell, 2) a wider ventral sulcus and dorsal fold starting at the beaks, 3 ) a very high, convex with parallel edges tongue, 4) clearly convergent dental plates, and 5) a more reduced septalium with a convex to flattened connectivum and a higher median septum. Xahetomus hexadaleidensis Sartenaer, 2009 (= Terebratula hexatoma Schnur, 1853, pl. 23, fig. 2f, g, non 2a-e), differs from Ferronirhynchia pulgari by the subcircular to subcordiform outline, maximum thickness slightly posterior to front, obtuse apical angle, wider and deeper sulcus and fold, higher, subtrapezoidal tongue and many other characters (compare Sartenaer, 2009, tabs. 2-3 with Tab. 1, herein). According to the present author (see above) all the Trigonirhynchia Cooper, 1942 species have a rounded subpentagonal outline, a globose profile, an obtuse apical angle, a very incurved ventral beak, a convex roofed ventral tongue, an excavated muscle field and greater size than Ferronirhynchia pulgari. In particular, the type species, T. fallaciosa (Bayle, 1878) differs from F. pulgari by having a marked cuboid profile, with shells as thick as long. Trigonirhynchia palentina García-Alcalde (in García-Alcalde \& Herrera, 2015) also differs in a greater size, more rounded costae and dental plates converging ventrally. Trigonirhynchia celtiberica Herrera (in García-Alcalde \& Herrera, 2015), is also greater than F. pulgari, with a convex ventral tongue, fewer costae, and a median costal formula $4 / 3$. Trigonirhynchia iranica Brice (in Brice et al., 2006), has more costae, more extensive lateral flanks, a convex roofed ventral tongue and a reduced septalium, with a very high median septum. Finally, Trigonirhynchia occidens (Walcott, 1884) is close to F. pulgari but it is somewhat greater and shows a cuboid profile, with more developed ventral sulcus and dorsal fold that start near the beaks, a convex tongue with parallel sides and more rounded costae.

\section{CONCLUSIONS}

The family Trigonirhynchiidae and, in particular, the subfamily Trigonirhynchiinae, is a puzzling taxon including a group of genera belonging to different superfamilies, fundamentally due to the misconception of the type genus, Trigonirhynchia (Cooper, 1942; see Uncinulina Bayle, 1878) by later authors. This fact has considerably hindered the discussion and classification of new related rhynchonellid forms. García-Alcalde (2009) began a necessary revision, segregating genera previously included in the family Trigonirhynchiidae based on the presence of a dorsal pseudoseptum and pseudoseptalium, in the new family Iberirhynchiidae of the Ancistrorhynchoidea. This review has been extended in the present paper refining the meaning, morphology, as well as the geographic and stratigraphic distribution of Trigonirhynchia. Based on the systematic perspective provided by the new data, a new trigonirhynchiid genus, Ferronirhynchia (including only the type species, F. pulgari n. sp.), is proposed. The pristine preservation of the studied $F$. pulgari populations provides an almost complete view of the ontogenetic development. Ferronirhynchia pulgari had, as usual in many other rhynchonellids, a bicyclic growth. The juveniles (biconvex, low and with sharp commissures) were morphologically very distant from adults (dorsibiconvex, with abrupt lateral and anterior paries geniculatus). But the juvenile-adult transition was heralded in the species by an intra-neanic growth stop represented by a characteristic prominent growth line, which is unique for the new genus. The adult length is highly variable, giving the wrong impression that the species was able to keep a longitudinal growth trend even after reaching the typical geniculate maturity profile. This anomaly is attributed to the occurrence of wide size variability along the late neanic/pre-ephebic growth stage. Ferronirhynchia pulgari inhabited quiet, muddy, poorly oxygenated environments, with limited food supply, where it played an opportunistic role. The species almost exclusively occurs as complete, well-preserved shells displaying the entire age range between the early neanic to the gerontic stages. The taphocoenosis is a close representation of the original biocenosis allowing a robust taxonomic definition of the species. Such muddy environment entails a significant risk of burial and death by suffocation. The species however, possessed a functional pedicle at all stages of development that allowed the brachiopod to stand out from the sea bottom and prevented it from being buried. This ability favoured a multitude of small encrusting organisms that fixed on shells, preferably on the ventral 
valve (the more distant from the bottom). Most of the individuals of $F$. pulgari were infested either by one or several superimposed different epizoan generations. The preferential settlement of epizoans at/along the commissures of the brachiopod shells suggests that they also benefited from part of the suspended food particles captured by the host's inhalant currents and, perhaps, from recyclable fractions of the expelled feces. In any case, the colonization did not disturb the brachiopods; therefore, the relationships would be commensalistic, even mutualistic, with epizoans forming a protective mask.

Supplementary Information. New taxonomic names proposed in this paper, and the nomenclatural acts it contains, have been registered in ZooBank, the online registration system for the ICZN: http://zoobank.org/References/ec4e31fc-6b4b4493-a6fb-e6275f2e974f

Author contributions J.G.-A. conceived the study, analysed the data, and wrote the manuscript.

Competing Interest. I declare I have no competing interests.

Funding. I received no funding for this study.

Author details. Jenaro L. García-Alcalde. Department of Geology, University of Oviedo, C/ Jesús Arias de Velasco, s/n, 33005 Oviedo, Spain; jalcalde@uniovi.es.

Acknowledgements. This paper is a contribution of the projects, CGL-2011-24775/BTE "Global events in the Lower Devonian of Spain and their worldwide correlation", of the Spanish Ministry of Economy and Competitiveness, CGL-2012/34475, "Processes of formation of "melanges" and other disorganized geological units", from the Ministry of Economy and Competitiveness, as well as IGCP 652 "Reading geologic time in Paleozoic sedimentary rocks: the need for an integrated stratigraphy". Dr. Julio Aguirre from the University of Granada made a first critical reading of the manuscript and revised the English text. I appreciate also the very careful revision by Dr. Jose Ignacio ValenzuelaRíos, from the University of Valencia, and Dr. Ulrich Jansen, from the Senckenberg Museum, Germany which contributed greatly to further improve the original version.

\section{REFERENCES}

Ahmadzadeh-Heravi, M. (1975). Stratigraphie und Fauna im Devon des östlichen Elburs (Iran). Clausthaler Geologische Abhandlungen, 23, 1-144.

Alekseeva, R. E. (1967). Brakhiopody i Stratigrafiya Nichnego Devona Severo-Vostoka SSSR [The Lower Devonian Brachiopoda and stratigraphy of the North-East of the USSR]. Akademia Nauk SSSR, Sibirskoe Otdelenie Institut Geologii i Geofiziki, Izdatelstvo.

Alekseeva, R. E., Mendbajar, B., \& Erlanger, O. A. (1981). Brakhiopody i biostratigrafiya Nichnego Devona Mongolii [Brachiopods and biostratigraphy of the Lower Devonian of Mongolia]. Sovmestnaya Sovetsko-Mongol'skaya Paleontologicheskaya Ekspeditsiya (SSMPE), Trudy, 16, 1-176.

Amsden, T. W. (1958). Stratigraphy and paleontology of the Hunton Group in the Arbuckle Mountain region. Part II.
Haragan Articulate Brachiopods. Oklahoma Geological Survey Bulletin, 78, 1-144.

Arbizu, M., García-Alcalde, J. L., García-López, S., MéndezBedia, I., Sánchez de Posada, L. C., Soto, F. M., Truyols, M., T ruyols, J., Álvarez, F., Méndez, C., \& Menéndez, J. R. (1979). Biostratigraphical Study of the Moniello Formation (Cantabrian Mountains, Asturias, NW Spain). A contribution to the Lower/Middle Devonian Boundary Problem. Geologica et Palaeontologica, 13, 103-124.

Baranov, V. V. (1991). Novye taksony Devonskikh rinkhonellid severo-vostoka SSSR [New Devonian rhynchonelloid taxa from northeastern USSR]. Paleontological Journal, $1,32-41$

Barrande, J. (1847). Üeber die Brachiopoden der silurischen Schichten von Böhmen. 1 Teil. Haidingers naturwisswenschappen Abhandlungen, 1, 357-475.

Bayle, E. (1878). Fossiles principaux des terrains de la France. Explication de la carte géologique de la France, 4(1), 80-158.

Bowen, Z.P. (1966). Boucotella, a New Silurian Rhynchonelloid Brachiopod Genus. Journal of Paleontology, 40(1), 186189.

Brice, D. (1981). Les Brachiopodes Pentamerida, Rhynchonellida et Terebratulida. In P. Morzadec, F. Paris, \& P. R. Racheboeuf (Eds.), La tranchée de la Lézais, Emsien supérieur du Massif Armoricain, étude paléontologique. Société Géologique et Minéralogique de Bretagne, Mémoires, 24(313), 193-223.

Brice, D. (1982). Brachiopodes du Dévonien inférieur des formations de Blue Fiord et Bird Fiord des Îles Arctiques canadiennes. Geological Survey of Canada Bulletin, 326, 1-175.

Brice, D. (2000). Brachiopodes du Silurien supérieur et du Dévonien inférieur (Praguien probable) de Khémis n'Ga (région de Safi), Maroc. In A. Tahiri, \& A. El Hassani (Eds.), Proceedings of the International Subcommission on Devonian Stratigraphy (SDS) - IGCP 421, Morocco meeting. Travaux de I'Institut Scientifique, Université Mohammed V, Série Géologie \& Géographie Physique, 20, 11-24.

Brice, D., Yazdi, M., Torabi, H., \& Maleki, A. (2006). Devonian brachiopods from the Zefreh section (Central Iran). Annales de la Société Géologique du Nord, 13, 141-155.

Cooper, G. A. (1942). New genera of North American brachiopods. Journal of the Washington Academy of Sciences, 32(8), 228-235.

Drot, J. (1971). Rhynchonellida siluriens et dévoniens du Maroc présaharien. Nouvelles observations. Notes du Service Géologique du Maroc, 31(237), 65-108.

Drot, J., \& Westbroek, P. (1966). Iberirhynchia santaluciensis, nouveau Rhynchonellacea du Dévonien de Léon (Espagne). Leidse Geologische Mededelingen, 38(1), 165-172.

Duméril, A. M. C. (1806). Zoologie analytique ou méthode naturelle de classification des animaux. Allais.

Fernández, L. P., Fernández-Martínez, E., García-Ramos, J. C., Méndez-Bedia, I., \& Soto, F. (1996). Devonian reef facies from the Cantabrian Zone (NW Spain). Informe interno, Departamento de Geología, Universidad de Oviedo.

García-Alcalde, J. L. (1996). El Devónico del Dominio AsturLeonés en la Zona Cantábrica ( $\mathrm{N}$ de España). Revista Española de Paleontología, Nº Extraordinario, 58-71.

García-Alcalde, J. L. (1998). Braquiópodos Rinconélidos del Lochkoviense (Devónico Inferior) de la Cordillera 
Cantábrica (Norte de España). Géobios, 31(6), 767-789. doi: 10.1016/S0016-6995(98)80108-3

García-Alcalde, J. L. (2001). Paleobiogeographical relationships between North Gondwana and South Baltica: The Ivanotyhyris havliceki fauna (Cantabrian Zone, latest Emsian). In J. Fryda, R. B. Blodgett, \& M. Mergl (Eds.), Havliček Volume. Journal of the Czech Geological Society, 46, 121-130.

García-Alcalde, J. L. (2009). Iberirhynchiidae nueva Familia de Rinconélidos Ancistrorhynchoideos (Braquiópodos) del Ordovícico Medio al Devónico Inferior de Euroamérica y Gondwana. Revista Española de Paleontología, 24(2), 149-169. doi: 10.7203/sjp.24.2.20353

García-Alcalde, J. L. (2015). La sucesión del Emsiense más alto-Eifeliense basal (Devónico) en el Dominio AsturLeonés de la Zona Cantábrica ( $N$ de España) y su fauna de braquiópodos. Trabajos de Geología, Universidad de Oviedo, 35, 41-98.

García-Alcalde, J. L., \& Herrera, Z. (2015). Braquiópodos del Devónico Inferior (Lochkoviense-Praguiense) de la región Cántabro-Celtibérica (España). Trabajos de Geología, Universidad de Oviedo, 35, 99-138.

García-Alcalde, J. L., Arbizu, M. A., García-López, S., \& Méndez-Bedia, I., Eds. (1979). Guidebook of the Field Trip. Meeting of the International Subcommission on Devonian Stratigraphy, Spain 1979. Servicio de Publicaciones de la Universidad de Oviedo.

García-López, S., \& Bastida, F., Eds. (2002). Palaeozoic conodonts from Northern Spain. Publicaciones del Instituto Geológico y Minero de España (serie Cuadernos del Museo Geominero, 1).

Havlíček, V. (1961). Rhynchonelloidea des böhmischen älteren Paläozoikums (Brachiopoda). Rozpravy Ústředního, ústavu geologického, 27, 1-211.

Havlíček, V., \& Štorch, P. (1990). Silurian brachiopods and benthic communities in the Prague Basin (Czechoslovakia). Rozpravy Ústředního, ústavu geologického, 48, 1-275.

Iordan, M. (1998). The Palaeozoic brachiopods of Romania. In Modern and Ancient Sedimentary Environments and Processes, Geo-Eco-Marina, 4/1999, 135-145.

Jahnke, H. (1971). Fauna und Alter der Erbslochgrauwacke (Brachiopoden und Trilobiten, Unter-Devon, Rheinisches Schiefergebirge und Harz). Göttinger Arbeiten zur Geologie und Paläontologie, 9, 1-105.

Johnson, J. G. (1970). Great Basin Lower Devonian Brachiopoda. Geological Society of America Memoirs, 121, 1-421. doi: https://doi.org/10.1130/MEM121

Jones, B., \& Smith, G. P. (1985). Paleoecology of the brachiopod faunas in the lower Devonian Eids Formation of southwest Ellesmere Island, Arctic Canada. Journal of Paleontology, 59(4), 957-974.

Kaesler, R. L., Ed. (2002). Treatise on Invertebrate Paleontology. The Geological Society of America \& The University of Kansas, Part H Brachiopoda Revised, Vol. 4, Rhynchonelliformea (part).

Kuhn, O. (1949). Lehrbuch der Paläozoologie. E. Schweizerbart'sche Verlagsbuchhandlung.

Méndez-Bedia, I. (1976). Biofacies y litofacies de la Formación Moniello-Santa Lucía (Devónico de la Cordillera Cantábrica, NW de España). Trabajos de Geología, Universidad de Oviedo, 9(9), 3-93.

Mergl, M., \& Massa, D. (2004). Devonian brachiopods of the Tamesna Basin (Central Sahara; Algeria and North
Niger). Part 1. Acta Musei Nationalis Pragae, Series B, Natural History, 60(3-4), 61-112.

Perry, D. G. (1984). Brachiopoda and biostratigraphy of the Silurian-Devonian Delorme Formation in the District of Mackenzie, the Yukon. Life Sciences Contributions, Royal Ontario Museum, 138, 1-243.

Perry, D. G., Klapper, G., \& Lenz, A. C. (1974). Age of the Ogilvie Formation (Devonian), Northern Yukon: based primarily on the occurrence of brachiopods and conodonts. Canadian Journal of Earth Sciences, 11(8), 1055-1097. doi: https://doi.org/10.1139/e74-104

Prado, C. de, \& Verneuil, E. de (1850). Note géologique sur les terrains de Sabero et de ses environs dans les montagnes de Léon (Espagne) (C. de Prado), suivie d'une déscription des fossiles de ces terrains (E. de Verneuil). Bulletin de la Société Géologique de France, 7(2), 137-186.

Roemer, C. F. (1844). Das Rheinische Uebergangsgebirge. Eine palaeontologische-geognostische Darstellung. Verlage der Hahn'schen Hogbuchhandlund.

Rozman, K. S. (1969). Pozdneordovikskie Brakhiopody Sibirskoi Platformy [Late Ordovician brachiopods of the Siberian Platform]. Paleontological Journal, 3, 86-108.

Sartenaer, P. (1970). Nouveaux genres rhynchonellides (brachiopodes) du Paléozoïque. Bulletin de l'Institut royal des Sciences naturelles de Belgique, 46(32), 1-32.

Sartenaer, P. (2007). Sapphicorhynchus, a new early Givetian rhynchonellid (brachiopod) genus from western New York State, USA, and Sapphicorhynchidae, n. fam. Bulletin de l'Institut royal des sciences naturelles de Belgique, Sciences de la Terre, 77, 41-61.

Sartenaer, P. (2009). Two new Emsian rhynchonellid (brachiopod) genera from the Eifel area (Germany). Bulletin de l'Institut royal des sciences naturelles de Belgique, Sciences de la Terre, 79, 27-42.

Savage, N. M. (2002). Rhynchotrematoidea. In R. L. Kaesler (Ed.), Treatise on Invertebrate Paleontology, part $\mathrm{H}$, Brachiopoda, revised, 4, Rhynchonelliformea (pp. 10471091). The Geological Society of America Inc. \& The University of Kansas.

Schmidt, H. (1937). Zur Morphogenie der Rhynchonelliden. Senckenbergiana, 19, 22-60.

Schmidt, H. (1965). Neue Befunde an paläozoischen Rhynchonellacea (Brachiopoda). Senckenbergiana lethaea, 46(1), 1-25.

Schnur, J. (1851). Die Brachiopoden aus dem Uebergangsgebirge der Eifel. Programm der vereinigten höhern Bürger- und Provinzial-Gewerbeschule zu Trier für das Schuljahr. Nabu Press.

Schnur, J. (1853). Zusammenstellung und Beschreibung sämmtlicher im Uebergangsgebirge der Eifel vorkommenden Brachiopoden. Palaeontographica, 3(4), 169-248.

Schuchert, C. (1913). Class 2. Brachiopoda. In K. A. von Zittel (Ed.), Text-book of Palaeontology, 1, 291-343. 1st edition traduced and edited by C. R. Eastman, MacMillan \& Co., Ltd.

Schumann, D. (1965). Rhynchonelloidea aus dem Devon des Kantabrischen Gebirges (Nordspanien). Neues Jahrbuch Geologie und Paläontologie Abhandlungen, 123(1), 41-104.

Selden, P. A., Ed. (2007). Part H Brachiopoda Revised, vol. 6, supplement. In Treatise on Invertebrate Paleontology. The Geological Society of America \& The University of Kansas. 
Soja, C. M. (1988). Lower Devonian (Emsian) brachiopods from southeastern Alaska, USA. Palaeontographica Abteilung A, 201(4-6), 129-193.

Tcherkesova, S. V. (1969). Rinkhonellidi semeistva Trigonirhynchiidae McLaren iz tareiskogo opornogo razreza (Tsentralni Taimir) [Rhynchonellids of the Subfamily Trigo nirhynchiidae McLaren from the Turkish reference section (Central Taimyr)]. Nauchno-Issledovatelskii Institut Geologii Arktiki, Ministerstva Geologii SSR, 26, 23-38.

Truyols-Massoni, M., \& García-Alcalde, J. L. (1994). Faune rhéno-bohémienne (Dacryoconarides, Brachiopodes) à la limite Emsien Inférieur/Supérieur au Cabo La Vela
(Asturies, Espagne). Géobios, 27(2), 221-241. doi: 10.1016/S0016-6995(94)80008-1

Walcott, C. D. (1884). Paleontology of the Eureka District. United States Geological Survey Monographs, 8, 1-298.

Westbroek, P. (1967). Morphological observations with systematic implications on some Palaeozoic Rhynchonellida from Europe, with special emphasis on the Uncinulidae. Leidse Geologische Mededelingen, 41, 1-82.

Westbroek, P. (1969). The interpretation of growth and form in serial sections through Brachiopods, exemplified by the trigonirhynchiid septalium. Palaeontology, 12(2), 321-332. 